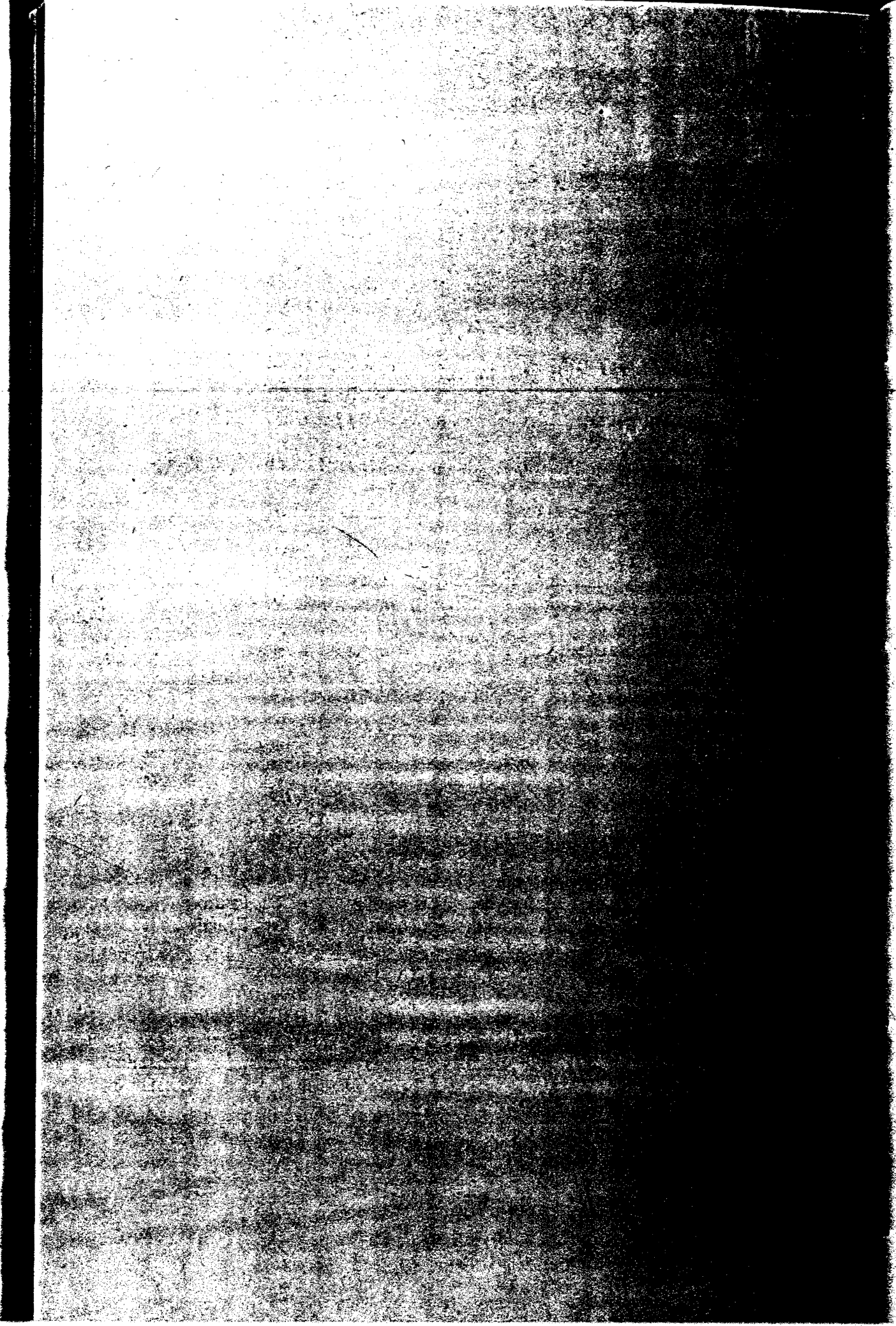

CAHIER 9237

ON THE (MIS)SPECIFICATION OF SEASONALITY AND ITS CONSEQUENCES : AN EMPIRICAL INVESTIGATION WITH U.S. DATA

Eric Ghysels ${ }^{1}$, Hahn S. Lee ${ }^{2}$ and Pierre L. Siklos ${ }^{3}$

1 Département de sciences économiques and Centre de recherche et développement en économique (C.R.D.E.), Université de Montréal.

2 Department of Economics, Tulane University.

3 Department of Economics, Wilfrid Laurier University.

\section{December 1992}

The first author would like to acknowledge the financial support of the SSHRC and NSERC of Canada, as well as the Fonds FCAR of Québec. Part of this paper was done while the first author was on sabbatical leave at the Cowles Foundation, Yale University. Its financial support and hospitality are also gratefully acknowledged. The third author is grateful for the hospitality of the University of California, San Diego where he was a visiting scholar during the spring of 1991, to Wilfrid Laurier University for financial support through a short-term research grant, a Course Remission Grant and the Academic Development Fund. Comments by an anonymous referee on an earlier draft helped improve the paper. A companion C.R.D.E. (Université de Montrél) working paper with a more detailed account of the empirical results is available upon request.
C.P. 6128 , sucoursale A Montrial
Tavcopiour (FAX): (514) 363-5831 Telcopiour (FAX): (514) 3a3-s331 


\section{RÉSUMÉ}

Il est bien connu qu'une erreur de spécification du "trend" produit de faux cycles dans les séries où loon a enlevé la tendance [e.g., Nelson et Kang (1981)]. Les procédures d'ajustement saisonnier sont basées sur des hypothéses implicites ou explicites sur les racines au cercleunité, aux fréquences saisonnières et à la fréquence zéro. En conséquence, les procédures d'ajustement saisonnier peuvent produire un faux "detrending" et d'autres effets statistiquemen indésirables.

Dans ce papier, on examine, pour une large classe de séries trimestrielles de données macroéconomiques américaines, les effets de différentes procédures d'ajustement saisonnier sur les propriétés de séries univariées ajustées. Nous considérons également quelles procédures sont appropriées, étant donné les propriétés des données. Dans lensemble, nous détectons des différences très significatives ainsi que l'évidence de faux cycles dans les séries fittrées par différentes procédures. Nous présentons également une extension des procédures de sélections de modèles dans les tests du type ADF, proposé par Hall (1990), à des tests du type HEGY.

Mots clés : désaisonnalisation et faits stylisés, procédures de test HEGY, sélection de modèle basée sur l'échantillon, tests de racine unitaire.

\section{ABSTRACT}

It is well known that misspecification of a trend leads to spurious cycles in detrended data [see, e.g., Nelson and Kang (1981)]. Seasonal adjustment procedures make assumptions, either implicitly or explicitly, about roots on the unit circle both at the zero and seasonal frequencies. Consequently, seasonal adjustment procedures may produce spurious detrending and other statistically undesirable effects.

In this paper, we document, for a large class of widely used U.S. quarterly macroeconomic Ce cahier a également été publié par le Centre de necherche et développent economique de l'Université de Montreal (publication

series, the effects of competing seasonal adjustment procedures on the univariate time series properties of adjusted series. We also investigate which procedures are most appropriate, given the properties of the data. Overall, we find very significant differences and evidence of spurious

Dépôt légal - quatrième trimestre 1992 Bibliotheque nationale du Canada nothents

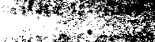

$\sin 3$ ISSN 0709,9231

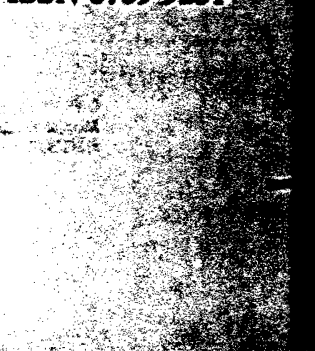

cycles among series fittered via different adjustment procedures. A byproduct of our paper is an extension of data-dependent model selection rules in ADF tests, proposed and analyzed by Hall (1990), to HEGY-type procedures.

Key words : seasonal adjustments and stylized facts, HEGY test procedures, data-based model selection, unit root tests. 
1. Introduction

Misspecification of a trend leads to spurious cycles in detrended data, as for instance Nelson and Kang (1981) emphasized. What is perhaps less obvious is the fact that seasonal adjustment procedures may produce similar effects. This paper takes up the question whether spuriousness is a problem when seasonals are removed via an adjustment procedure based on a misspecified model of seasonality.

There exists, of course, a vast literature about the ideal properties seasonal adjustment procedures should have, including the fact that they should leave the time series properties of the series unaffected except at the seasonal frequencies (see e.g. Nerlove ot al. (1979), Bell and Hillmer (1984) and Hylleberg (1986) for surveys and detailed discussion). As is now well known, many time series are nonstationary and they are widely believed to contain a unit root at the zero frequency (see Campbell and Perron 1991 for a recent survey). Similarty, usual seasonal adjustment procedures make either implicitly or explicitly assumptions about roots on the unit circle both at the zero as well as at the seasonal frequency and its harmonics. Typically, in applied research, adjustment for seasonality assumes that seasonality is deterministic and can be removed via seasonal dummies thus ignoring the possibility of the stochastic and nonstationary nature of seasonality. On the other hand, the commonly applied monthly Census $X-11$ program. for instance, implies data transformations which include the $\left(1+L+L^{2}+\ldots .+L^{11}\right.$, where $L$, , is the lag operator for $i$ periods) filter, resulting in a "removal" of unit roots at the monthly seasonal frequency and its hamonics.'

Data transformations that go along with the removal of seasonals may or may not be appropriate, just like trend removal can be inadequately done. In this paper we document for a large class of quarterly U.S. Post World War II time series how several of the data transiormations typically associated with seasonal adjustment affect the univariate time series properties of interest to economists, such as the autocorrelation and partial autocorrelation functions of the transformed data. In addition, we use tests proposed by Hylleberg, Engle, Granger and Yoo (1990; henceforth HEGY) to determine which data transformation appears to be most appropriate.

\footnotetext{
${ }^{1}$ For a discussion of the X-11 fitter and its linear approximation see e.g. Chysels and Perron (1992).
} 
With one exception, all the data transformations we consider imply the same treatment with regard to zero frequency detrending. Namely, all transformations assume the data have a unit root at the zero frequency except for the case where a first difference is combined with a seasonal difference. In the latter case we obtain two unit roots at the zero frequency. All seasonal adjustment data transformations differ, however. with regard to the treatment of deterministic and stochastic seasonality and the presence of unit root at seasonal frequencies in the stochastic case. In general, $h$ is found that summary statistics of the data are quite sensitive to the way seasonal adjustment is applied. Very different conclusions can be found for the univariate characterization of the data depending on the way seasonals are eliminated even with the detrending being kept constant across different adjustment procedures.

A by-product of our paper is a theoretical extension of the HEGY procedure. As they involve an AR polynomial expansion, similar to Dickey-Fuller tests for unit roots at the zero frequency, one has to select a lag length to calculate the tests. Recently, Hall (1990) derived the limiting distribution of the augmented Dickey-Fuller test when the AR polynomial expansion is chosen using data-based methods, as is most often done in practice. We extend Hall's zero frequency results to HEGY tests for unit roots at the zero and seasonal frequencies.

It may be worth emphasizing a few limitations of our paper. We will only discuss the effect of fittering on the univariate characterization of data and not the consequences of fittering on estimation and testing. Hence, we will not elaborate on the issue of fittering and estimation and testing, in part because this subject is documented in detail in for instance Sims (1974), Wallis (1974), Sims (1985), Ghysels and Perron (1992), Hansen and Sargent (1992), Sims (1992), among others.

The paper is organized as follows. In Section 2 we discuss the autocorrelation and partial autocorrelation functions of a representative set of U.S. quarterty time series after being adjusted with a set of five commonly used fitters for removal of seasonal fluctuations. Next, we present a summary of the HEGY procedure and extend it to allow for data based augmentation lag selection. Empirical results of the HEGY procedure are reported in Section 3. Conclusions appear in Section 4.

\section{Univarlate Time Serles Propertles of U.S. Quarterly Data}

Quarterly data on a variety of U.S. macroeconomic series were considered similar to Barsky and Miron (1989; hereafter BM) whose sample usually begins in 1946 and ends in 1985 (see their Table 1). Not all of the series used by BM were considered in this paper. We omitted the components of fixed investment expenditures, the money multiplier, state and local government spending, and final sales. However, we added per capita versions of GNP and consumption expenditures and its components as well as a measure of real balances. ${ }^{2}$ We did, however, also update the data used by BM up to the fourth quarter of 1989. In the results reported below, we report only the test results for the extended sample. 3

Table 1 displays the sample autocorrelations (hencelorth denoted AC) for three of the key macroeconomic time series considered in this paper which are "seasonally adjusted" using a selection of fitters. The aim is to illustrate divergent patterns in the autocorrelation and partial autocorrelation functions subjected to different filters. The data transformations considered are those typically associated with adjustment for seasonality. The most prominent of course is the official $X-11$ adjustment procedure used by the U.S. Bureau of the Census. The entry $\Delta_{S A}$ corresponds to the first differenced seasonally adjusted series by the Census. The transformation associated with $\Delta_{S A}$ assumes a unit root at the zero frequency as well as the seasonal frequency and its harmonics." A transformation making the same assumptions is taking the annual, i.e., fourth order difference which is denoted by $\Delta_{4}$. It should be noted though, that $\Delta_{\text {SA }}$ and $\Delta_{4}$, while making the same assumptions about roots in the unit circle, entail quite different data transformations. The fourth difference is a tailty transparent transformation while $\Delta_{\text {sA }}$

\footnotetext{
${ }^{2}$ Since there were no differences between the real and real per capita measures of GNP and consumplion the results for the laner series are not reportod in the main boty of the pepper.

${ }^{3}$ Conchusions are generally unaffected by the addition of the 16 mose rocent quarnety observations. Sec, however, section 4 below. These, and the dane are available from the third andhor upon request. Some lest results for the smple used by BM are reported in the appendix of the working peper version.

4 The rectnical details of this argument are omitted here. They con be sumamerived as follows: it is assumed that the X-11 procedure is applied to the monthly dexa first which is then atgregmed wo quanterly series. The moothly $X-11$ fiker contains the sub-filter $\left(1+L+\ldots+L^{11}\right)$, as discussed in Bell (1992) removing unit roots an the monthly seasonal frequency and its harmonies. Temporal aggregation to quanenty series wit make this equivalent $10(1+L$ $+L^{2}+L^{3}$ ). See Granger and Siklos (1992), and Hylleberg et al. (1992), for forther discussion of temporal akgercation and semsonal unit ronts.
} 
corresponds to several transformations including judgemental corrections, aggregation

TABLE 1

Autocorrelations of Some Key Macroeconomic Varlables with Different Seasonal Adjustment Fitters

\begin{tabular}{|c|c|c|c|c|c|c|c|c|c|}
\hline \multirow[b]{3}{*}{ Series } & \multirow[b]{3}{*}{ Transform } & \multicolumn{8}{|c|}{ Autocorrelations } \\
\hline & & \multicolumn{8}{|c|}{ Lag } \\
\hline & & 1 & 2 & 3 & 4 & 5 & 6 & 7 & 8 \\
\hline \multirow[t]{6}{*}{ GNP } & Level & .98 & .96 & .94 & .92 & .90 & .89 & .87 & .85 \\
\hline & $\Delta$ & -.60 & .34 & -.61 & .80 & -.63 & .32 & -.60 & .66 \\
\hline & $\Delta_{4}$ & .83 & .54 & .22 & -.06 & -.18 & -.16 & -.07 & .04 \\
\hline & $\Delta_{\text {SA }}$ & .37 & .25 & .00 & -.10 & -.12 & -.06 & -.02 & -.08 \\
\hline & $\Delta-S D$ & -.02 & -003 & -.15 & .38 & -.28 & -.13 & -.15 & .31 \\
\hline & $\Delta \Delta_{4}$ & .32 & .12 & -.12 & -.46 & -.36 & -.21 & -.07 & -.00 \\
\hline \multirow[t]{7}{*}{ Cons. } & Level & .98 & .97 & .95 & .93 & .92 & .90 & .88 & .86 \\
\hline & $\Delta$ & -.68 & .41 & -.67 & .94 & -.65 & .39 & -.65 & .91 \\
\hline & $\Delta_{4}$ & .78 & .65 & .50 & .32 & .33 & .30 & .35 & .38 \\
\hline & $\Delta_{\text {SA }}$ & .05 & .22 & .04 & -.03 & -.06 & -.12 & .05 & -.18 \\
\hline & $\Delta-S D$ & -.41 & .30 & $\cdot .38$ & .61 & -.30 & .19 & -.32 & .54 \\
\hline & $\Delta_{4}$ & -.22 & .13 & .03 & -.43 & .11 & -.21 & .08 & -.02 \\
\hline & $\Delta \Delta_{4}$ & -.20 & .14 & .08 & -.37 & .14 & -.21 & .10 &. .10 \\
\hline \multirow[t]{6}{*}{ M1 } & Level & .98 & .96 & .94 & .91 & .89 & .87 & .84 & .82 \\
\hline & $\Delta$ & .10 & -.15 & .01 & .72 & .02 & -.16 & -.05 & .66 \\
\hline & $\Delta_{4}$ & .92 & .80 & .67 & .56 & .50 & .46 & .41 & .37 \\
\hline & $\Delta_{\text {SA }}$ & .57 & .40 & .30 & .17 & 29 & .26 & .09 & .06 \\
\hline & $\Delta-S D$ & .36 & .16 & .21 & .50 & .21 & .10 & .08 & $-\mathbf{4 1}$ \\
\hline & & $\Delta \mathbf{\Delta}_{4}$ & .31 & .05 & -.04 & -.40 & -.02 & .05 & -14 \\
\hline
\end{tabular}

All series are seasonally unadjusted except for the $\Delta_{\text {sA }}$ fitter which relies on seasonally adjusted data at the source. All series are in logarithms of the levels except for the change in business inventories, the unemployment rate, treasury bill rate, and ex post real interest rate, which are in levels. across industries, time, etc.

Other transformations considered in Table 1 include a first difference with seasonal dummies, denoted $\Delta-S D$, and a multiplicative $\Delta \Delta_{4}$ adjustment advanced by Box and Jenkins (1976). The former assumes a deterministic seasonal pattem, while the latter takes two unit roots at the zero frequency. ${ }^{5}$

For the purposes of comparison, we also listed the AC function for the level of the series as well as the first difference where seasonals are ignored. Let us first discuss in detail the first series listed in Table 1, namely US GNP. The autocorrelation at lag 1 ranges from .98 to -.60 depending on which transformation (or lack of it) is considered. The .98 value comes, of course, from the level series but, even with $\Delta_{4}$, the removal of the annual seasonal still leaves a very high autocorrelation at the first lag equal to .83 . The differences between the Census adjusted result of .37 and the common transformation $\Delta-S D$ (yielding -.02) suggests that transformations can have important effects on some of the time series properties of the data.

The differences in the pattems displayed in Table $t$ for GNP are fairty representative for the other cases as well. Consumption and M1 are just two of the examples appearing in Table 1 (additional details are also contained in the discussion paper version).

What is clearty to be concluded, as a first impression from the results in Table 1 , is that modelling seasonality, and the adjustment of data on the basis of such a model, seems to greatly affect whatever is left in univariate time series behavior at lags other than the seasonal ones. The question which needs to be raised then is which data

\footnotetext{
5 The transformation which consists in eliminating the pair of roots $(1-L)$ or $(1-L)(1+L)$ corresponding to the biannual frequency apperently common in many macroeconomic time series (e.g. Lee and Siklos (19912. 1991c) was also considered. The results are contained in the Appendix of the companion discussion paper.
} 
transformation appears most appropriate. For that, we tum to the issue of testing for unit roots at the seasonal frequency as each of the data transformations considered treat this key feature difterently.

\section{The HEGY Procedure with Preceat Deta Beeed Modal Selection}

In order to ascertain the presence of unit roots at the seasonal frequencies, as well as at the zero frequency, we follow the procedures outlined by HEGY, and applied by Beaulieu and Miron (1992), Engle, Granger, Hylleberg and Lee (1992), Franses (1991), Lee and Siklos (1991a), Otto and Wirjanto (1991), among others. Moreover, Ghysels, Lee and Noh (1991) found the HEGY procedure compares favorably with altemative procedures such as the Dickey, Hasza and Fuller (1984) tests, in terms of finite sample size and power properties. In this section we introduce the HEGY procedure. Since it has been widely documented elsewhere our discussion will be brief. Our main focus of attention will instead be directed towards extending the HEGY procedure to take accoumt of the fact one usually determines the order of the AR polynomial expansion used in the fest on the basis of the data. The fact that the lag length selection is data-based o w a t something usually lgnored in theory but quite relevant and important in practice, restits in some nontrivial distributional issues regarding the test statistics. Recently, howevis, work by Hall (1990) deals with data-based model selection in tests for unit roots at thes zero frequency. We extend Halls results to that of HEGY procedures.

The HEGY approach consists in estimating the following regression:

$$
\begin{aligned}
\Delta_{4} x_{1}=\pi_{1} y_{1, t-1} & +\pi_{2} y_{2, t-1}+\pi_{3} y_{3, t-2}+\pi_{4} y_{3, t-1}+\mu+\beta^{\prime} D_{t} \\
& +\delta c+a_{1} \Delta_{4} x_{t-1}+a_{2} \Delta_{4} x_{t-2} \\
& +\cdots+a_{p} \Delta_{4} x_{t-p}+\varepsilon_{1}
\end{aligned}
$$

where $\mu$ is a constant, $\delta$ is the slope coefficient of the linear trend, $D_{1}$ is a vector containing three deterministic seasonal dummies with coefficient vector $\beta,\left(a_{1}, \ldots, a_{p}\right)$ are the AR lag augmentations, and the $y_{k t}$ 's $(k=1,2,3)$ are series adjusted for unit roots at other frequencies such that

$$
\begin{aligned}
& y_{1 t}=\left(1+L+L^{2}+L^{3}\right) x_{1} \\
& y_{2 t}=-\left(1 \cdot L+L^{2}-L^{3}\right) x_{4} \\
& y_{3 t}=-\left(1 \cdot L^{2}\right) x_{4}
\end{aligned}
$$

Thus, $y_{1 t}$ is the series $x_{1}$ after all seasonal unit roots have been removed, leaving only a unit root at the zero frequency. By contrast $y_{2 t}$ leaves a unit root at the bi-annual frequency for quarterly data so that $(1+L) y_{2 t}$ is stationary; $y_{3 x}$ then possesses a pair of complex roots of the annual frequency so that $\left(1+L^{2}\right) y_{3 i}$ is stationary.

The test for the presence of unit roots is based on the t-statistic for $\pi_{1}$, for the zero frequency, $\pi_{2}$ for the biannual frequency. For the annual frequency we require a joint test on $\pi_{3}$ and $\pi_{4}$, namely an F-test of the null hypothesis that $\pi_{3}=\pi_{4}=0$. Attematively, the t-statistic on $\pi_{3}$, when $\pi_{4}=0$, may be used. Critical values for the tests were tabulated by HEGY (1990), and the asymptotic distribution theory is discussed in Engle, Granger, Hylleberg and Lee (1992). 
A key assumption typically made both in the application of augmented DickeyFuller tests (henceforth denoted ADF) as well as the HEGY procedure is that the AR lag augmentation $\mathrm{p}$ is known a priori. Yet, in many applications this assumption is not appropriate as researchers usually decide on the value of $p$ on the basis of the available data. As noted by Hall (1990), it is clear that if $p$ is chosen using a data-based model selection procedure, like testing which AR coefficients are significant etc., then the ADF test, or the HEGY procedure, are actually based on a pretest estimator. Whether or not the asymptotic distribution of the ADF fest changes, and for which model selection rules it doesn't, has also been studied by Hall. Drawing on his analysis and the results in Ghysels, Lee and NCh (1991) showing the correspondence between ADF and HEGY test will enable us to extend Halrs analysis to the HEGY procedure.

Consider first the data generating process the HEGY procedure is designed to test:

$$
x_{t}=\mu_{0}+\alpha x_{t-4}+\mu_{t} \quad t=1, \ldots, T
$$

where the error process has a AR( $\left(p_{0}\right)$ representation, namely

$$
\mu_{j}=\sum_{j=1}^{p_{0}} \theta_{j} \mu_{i-j}+e_{j}
$$

The set-up in equations (3.2) and (3.3) portrays the data generating processes that 90 along with null and alternative hypotheses of HEGY procedures. For simplicity, though not without loss of generality, we stripped away the time trend and seasonal dummies. Hence with $\alpha=1$ in (3.2) we obtain a unit root all four frequencies of interest. In addition. the seasonal differenced process $\Delta_{4} x_{1}$ follows an $A R\left(p_{0}\right)$ process which is the raison ơ'etre for discussing AR augmentation. In particular, let:

\section{Assumption 3.1:}

(1) The initial vector $\left(x_{0}, x_{-1}, \ldots, x_{-p_{0}-3}\right)$ has a fixed distribution independent of $\left\{\theta_{1}\right\}$.

(2) The roots of the characteristic equation of the AR(po) polynomial in (3.3) lie outside the unit circle.

(3) The sequence of innovations $\left\{\theta_{\}}\right\}$are i.i.d. zero mean and constant variance $\sigma^{2}>$ o.

The order $p$ of the AR expansion in the HEGY equation (3.1) is selected by using a model selection procedure applied to the data. Namely, assume that $p=p_{T}$ is selected as the estimated value of $p_{0}$. The estimated AR expansion has a well-defined probability distribution for any sample size $T$ and $\Pi\left(\rho_{T}=j\right)$ represents the probability of obtaining an expansion of order $\mathrm{j}$, where $\mathrm{j}=0,1, \ldots, \mathrm{J}<\infty$. Moreover, for any $\hat{B}_{\mathrm{T}}=\mathrm{j}$ we define the tstatistics $t_{y}$ where $i=1, \ldots, 4$ corresponding to the OLS estimates of $\pi_{1}$ through $\pi_{4}$ in the HEGY equation (3.1). The following assumption will be key to the main result.

\section{Assumption 3.2:}

The model selection procedure satisfies the following conditions:

(1) as $T \rightarrow \infty, P_{T}-P_{0} \stackrel{P}{\rightarrow} O$ where $\stackrel{P}{\rightarrow}$ has a well defined probability distribution;

(2) the distribution of $p_{T}$ is independent of the distribution of the statistics $h_{\mathrm{C}}$ for $\mathrm{i}=1, \ldots$ , 4, $=0$... J and all $\mathrm{T}$.

(3) $\quad \Pi\left(\beta_{T}<P_{0}\right)=0$, i.e. the probability of underestimating $P_{0}$ is zero as $T \rightarrow \infty$. The latter of the three conditions is important as it guarantees the convergence of the 1 -statistics of the HEGY procedure to their distribution as characterized in Engle, Granger, Hylleberg and Lee (1992). Hence, under assumption 3.2 the model selection rule leaves the test statistics unaffected. This is summarized in the following theorem, with the proof appearing in the appendix to the paper. 


\section{Theorem 3.1:}

Let assumption 3.1 and 3.2 hold, then using $P_{T}$ to determine the AR lag expansion in the OLS equation (3.1) yields the asymptotic distributions:

$$
\begin{aligned}
& t_{1 j} \Rightarrow\left\{w_{1}(1)^{2}-1\right] / 2\left[\int_{0}^{1} w_{1}(r)^{2} d r\right]^{1 / 2} \\
& t_{2 j} \Rightarrow\left(w_{2}(1)^{2}-1\right] / 2\left[\int_{0}^{1} w_{2}(r)^{2} d r\right]^{1 / 2} \\
& \left.\left.t_{3 j} \Rightarrow \int_{0}^{1}\left(w_{3} d w_{3}+w_{4} d w_{4}\right)\right]\left[\int_{b}^{1}\left(w_{3}(r)\right)^{2}+w_{4}(r)^{2}\right) d r\right]^{1 / 2} \\
& \left.t_{4 j} \Rightarrow \int_{0}^{1}\left(w_{3} d w_{4}+w_{4} d w_{3}\right)\right)\left[\int_{0}^{1}\left(\left(w_{3}(r)\right)^{2}+\left(w_{4}(r)\right)^{2}\right) d r\right]^{1 / 2}
\end{aligned}
$$

where $\Rightarrow$ denotes weak convergence in distribution, $J=\rho_{T}$ and $w_{j}(r),(i=1,2,3,4)$, are standard Brownian notions on the unit intervals $[0,1]$.

The proof of the theorem appears in the appendix. We should note that several model selection criteria satisfy the assumption 3.2. Hall (1990) discusses several of them and analyzes their relative merits via a Monte Carlo investigation. While several of the criteria yield more or less similar results Halrs simulations showed a slight advantage to using what is known as a generatto-specific model selection rule starting with some upper bound on the length of the AR expansion. In the final analysis, the length of the AR expansion is determined by the longest statistically significant lag, where statistically significant means at a conventional significance level such as $5 \%$ or $10 \%$. The application of this selection procedure outperformed the resort to selection criteria such as the Hannan and Quinn criterion in particular. We conducted our empirical tests by utilizing the generat-10-specific search procedure as well as the ACC and BIC criteria. Since there was Wittle differences in the empirical results with the different criteria, and since the simulation evidence in Hall tended to favor the generalto-specific rule, we will only report the empirical evidence with the latter in the following section.

\section{Testing for Seasonal Unit Roots}

We now report test results to determine whether there is evidence of seasonal unit roots. Table 2 contains empirical evidence based on the HEGY procedure described in section 3 above. Such tests will allow us to shed some light on which transformation is the most appropriate for generating the stationary component of a particular time series. Table 2 indicates whether the hypothesis of a unit root at the seasonal and zero frequencies can be rejected. If not. Table 2 labels such a result by a 1 , an indication that the time series in question is integrated of order one or I(1). Otherwise, Table 2 labels a result with a zero because the series is $\mathrm{I}(0)$ at the frequency in question. All inferences are based on a 5\% significance level. Moreover, Table 2 only shows test results for the case where equation (3.1) includes a constant, a trend, and deterministic seasonal dummies. The volume of results precludes a complete description of test outcomes for all the combinations of equation (3.1) which could have been considered.

The sensitivity of unit root findings may be influenced by the choice of lag length selection criteria for the autoregressive correction factor in equation (3.1). Akaike's information criterion (AIC) and Schwartz's information (SC) are well known and cornmonly employed criteria. EGHL (1992) rely on the "augmentation" approach which consists, first, in estimating equation (3.1) for some lag length (seven quarters in the present case). One then establishes which of the lags are statistically significant say at the $5 \%$ level. Finally, one reestimates equation (3.1) by including only the statistically significant autoregressive correction terms. The net result is to leave gaps or "holes" in the lag distribution of the AR terms in equation (3.1). The rationale for this approach is "to whiten 
the residuals at the cost of the minimum number of parameters. Too many parameters will decrease the power of the tests while too few will render the size far greater than the level of significance:" (EGHL 1992). Based on Hall (1990), however, the preferred approach consists in estimating the number of AP terms in equation (3.1) according to the longest lag with a statistically significant coefficient, beginning with a maximum lag length of 7 quarters. Below we report results using such a test procedure, again at the $5 \%$ level of significance. To conserve space we only present test results in Table 2 based on the general-to-specific selection path. It should be noted, however, that the finding of an $I(1)$ or $I(0)$ was not generally sensitive, especially at the zero frequency, to the lag selection technique."

Tuming to the resulis, $i$ is apparent, especially from the last column of Table 2. that very few series possess a unit root at the annual frequency. The only exceptions are total consumption spending, consumption of non-durables, and the average real wage. These results reinforce the comparative difficulty of finding seasonal unit roots at the annual frequency found by other researchers using macroeconomic data from other countries such as Canada and Japan (e.g., Leo and Siklos 1991, and EGHL 1992, respectively). This also means that the $\Delta_{4}$ filler advocated

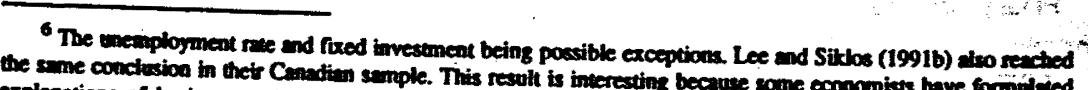

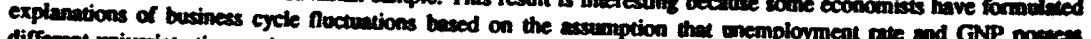

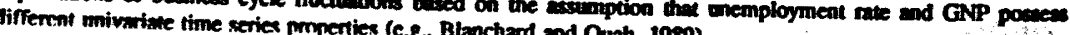

TABLE 2

Seasonal Unit Root Test Results: HEGY Method" Samplo ends in 1989.4

\begin{tabular}{|c|c|c|c|c|c|c|c|}
\hline \multirow[b]{2}{*}{ Series } & \multicolumn{2}{|c|}{ Lag Selection } & \multicolumn{5}{|c|}{ Coefficients in (3.1) } \\
\hline & Criterion & [lags] & $\pi_{1}$ & $\pi_{2}$ & $\pi_{3}$ & $\pi_{4}$ & $\pi_{3} \cap \pi_{4}$ \\
\hline GNP & Longest sig. lag & [1] & 1 & 1 & 1 & 0 & 0 \\
\hline Consumption & & [5] & 1 & 1 & 1 & 0 & 1 \\
\hline $\begin{array}{l}\text { Consumption } \\
\text { Non-Durables }\end{array}$ & & [5] & 1 & 1 & 1 & 1 & 1 \\
\hline $\begin{array}{l}\text { Consumption } \\
\text { Durables }\end{array}$ & & {$[0]^{\circ}$} & 1 & 0 & 0 & 0 & 0 \\
\hline $\begin{array}{l}\text { Consumption } \\
\text { Services }\end{array}$ & & [5] & 1 & 1 & 0 & 1 & 0 \\
\hline Fixed investment & & [1] & 0 & 0 & 0 & 0 & 0 \\
\hline Government Exp. & & [1] & 0 & 0 & 0 & 0 & 0 \\
\hline $\begin{array}{l}\text { Govemment Exp. } \\
\text { Federal }\end{array}$ & & [0] & 1 & 0 & 1 & 0 & 0 \\
\hline $\begin{array}{c}\text { Govemment Exp. } \\
\text { Defense }\end{array}$ & & {$[0]^{\circ}$} & 1 & 0 & 0 & 0 & 0 \\
\hline Exports & & [1] & 1 & 0 & 0 & 0 & 0 \\
\hline Imports & & [0] & 1 & 0 & 0 & 0 & 0 \\
\hline $\begin{array}{l}\text { Change in Bus. } \\
\text { Inventories }\end{array}$ & & [5] & 0 & 1 & 0 & 0 & 0 \\
\hline Employment & & [1] & 1 & 0 & 1 & 0 & 0 \\
\hline Unemployment & & [1] & 0 & 0 & 1 & 0 & 0 \\
\hline Average Hours & & [0] & 1 & 0 & 1 & 0 & 0 \\
\hline Labor Force & & [1] & 1 & 0 & 0 & 0 & 0 \\
\hline Cons. Price Index & & [0] & 1 & 0 & 0 & 0 & 0 \\
\hline
\end{tabular}


TABLE 2 (Continued)

\begin{tabular}{|l|cc|c|c|c|c|c|}
\hline \multirow{2}{*}{ Series } & \multicolumn{3}{|c|}{ Lag Selection } & \multicolumn{4}{c|}{ Coefficients in (3.1) } \\
\cline { 2 - 8 } & Criterion & [lags] & $\pi_{1}$ & $\pi_{2}$ & $\pi_{3}$ & $\pi_{4}$ & $\pi_{3} \cap \pi_{4}$ \\
\hline Interest Rate & {$[4]$} & 1 & 0 & 0 & 0 & 0 \\
\hline $\begin{array}{l}\text { Expost real } \\
\text { interest rate }\end{array}$ & {$[0]$} & 0 & 0 & 0 & 0 & 0 \\
\hline Average Wage & {$[2]$} & 1 & 0 & 1 & 0 & 0 \\
\hline $\begin{array}{l}\text { Average Real } \\
\text { Wage }\end{array}$ & {$[7]$} & 1 & 0 & 1 & 1 & 1 \\
\hline Monetary Base & {$[0]$} & 1 & 0 & 0 & 0 & 0 \\
\hline Money Supply-M1 & {$[1]$} & 1 & 0 & 1 & 0 & 0 \\
\hline Real Balances & {$[5]$} & 1 & 0 & 0 & 0 & 0 \\
\hline
\end{tabular}

1 Based on estimates of equation (3.1). A constant, trend, and deterministic seasonal dummies are included.

- Signifies that the test resulk for the $x$, coefficient differed as between the seasonally adjusted and unadjusted series. by Box and Jenkins is generally unwarranted. The implication then is that, as in Osbom (1990), Box and Jenkins type adjustments which ignore deterministic seasonality can be mis-specified. ${ }^{7}$ Moreover, since there are differences in the stochastic behaviour of consumption and income at the seasonal frequencies. These results may also have implications for the estimation and interpretation of consumption functions (see Lee and Siklos 1991a).

There is, however, more evidence of roots on the unit circle at the biannual frequency. For total consumption, consumption of non-durables, consumption of services, the change in business inventories and GNP. If we restrict the analysis to the sample chosen by Barsky and Miron (1989) there is still more evidence of a seasonal unit root at the bi-annual frequency since for the labour force and wages series, one cannot reject the null that $\pi_{2}=0$, in addition to the series found to have a bi-annual seasonal unit root for the extended sample. However, the foregoing exceptions to the finding of no seasonal unit roots at the bi-annual frequencies are interesting. For example, in the case of the inventory series, the omission of stochastic seasonality may have implications for models which purport to show a link between inventory fluctuations and business cycles (e.g., see Ramey 1989, and references therein). The finding of a seasonal unit root for the services component of total consumption reveals the possible importance of aggregation in estimating economic relationships such as the consumption function. Thus, the seasonal unit root tests reveal potentially a considerable amount of mis-specification of seasonality when only deterministic seasonality is assumed to exist.

This confirms not only the outcome of most unit root tests at the zero frequency, applied to a wide variety of U.S. seasonally adjusted macroeconomic data by several

\footnotetext{
${ }^{7}$ As noted previously, we conducted all our tests with and without deterministic seasonals and omission of the latter feature of the data influences the conclusions reached in Table 2 .
} 
researchers (see Campbell and Perron 1991 for a recent survey), but also reaffirms the neutrality of the X-11 seasonal adjustment procedure with respect to its impact on the existence of a unit root (see Lee and Siklos 1991 for Canadian evidence). One must, therefore, conclude that while deterministic seasonal dummies capture much of the seasonal variation $\mathrm{h}$ the data there is sufficient evidence of the existence of seasconal unit roots to warrant the statement that the no seasconal unil root approach leads to misspecification of univariate time series behaviour. This "In between" result is probably best explained by arguments along the lines of changing seasonal patterns, see Ghysels (1991), and Canova and Ghysels (1992). Indeed, changes in seasonal pattems will not be captured by seasonal pattems and will lead to spurious findings of roots at seasonal frequencies.

\section{Conclusions}

This paper has investigated the properties of various filters applied for the purposes of seasonal adjustment. Examination of autocorrelation and partial autocorrelation functions for widely used US quarterly macroeconomic time series suggests considerable differences across the various data transformations considered. We also extended Hall's work on the issue of lag length selection in unit root tests to the unit root test introduced by HEGY.

The empirical results suggest that, while seasonal dummies capture a great deal of seasonal pattems, they do not seem to adequately describe all attributes. Indeed, unit roots at some seasonal frequencies are regularty found. Moreover, none of the standard transformations typically used to remove seasonals match the findings emerging from HEGY data-based model selection rules. One possible explanation for our findings is that seasonal patterns change, only occasionally though, as noted in Ghysels (1991) and
Canova and Ghysels (1992). As such, none of the standard transformations suit this framework. Moreover, whatever transformation is applied seems to have a great impact on what is left as nonseasonal variation. 


\section{References}

R.B. Barsky and J.A. Miron (1989), "The Seasonal Cycle and the Business Cycle," Journal of Polltical Economy, 97 (June 1989), 503-34.

J.J. Beaulieu and J.A. Miron (1990), "Seasonal Unit Roots in Aggregate U.S. Data," Menuscript (Department of Economics, Boston University).

W.R. Bell (1992), "On Some Properties of Linear Approximations to the X-11 Program, Statistical Research Division, U.S. Bureau of the Census (mimeo).

W.R. Bell and S.C. Hillmer (1984), "Issues Involved with Seasonal Adjustment of Economic Time Series," Journal of Business and Economic Statistics 2,526 Econom.

O.J. Blanchard and D. Quah (1989), The Dynamic Eflects of Aggregate Demand and Aggregate Supply Disturbances," American Economic Revlew, 79 (September 1989), 655-73.

F. Canova, and E. Ghysels (1992). "Changes in Seasonal Pattems: Are They Cyclical?" Discussion Paper, Université de Montréal.

D.A. Dickey, W.R. Bell and R.B. Miller (1986), "Unit Roots in Time Series Models: Tests and Implications," The American Statisticlan 40, 12-26.

D.A. Dickey, D.P. Hasza and W.A. Fuller (1984). "Testing for Unit Roots in Seasona Time Series," Journal of the American Statistical Association 79, 355-367.

R.F. Engle, C.W.J. Granger, S. Hylleberg, and B.S. Yoo (1990), "Seasonal Integration and Cointegration," Joumal of Econometrics, 44, 215-38.

P.H. Franses (1991). "A Multivariate Approach to Modeling Univariate Seasonal Time Series," Econometric Institute Report No. 910/A.

E. Ghysels (1991), "On Seasonal Asymmetries and their Implications for Stochastic and Deterministic Models of Seasonality," manuscript, Université de Montréal.

E. Ghysels, H.S. Lee and J. Noh (1991), Testing for Unit Roots in Seasonal Time Series - Some Theoretical Extensions and a Monte Carlo Investigation." Disc. Paper, C.R.D.E. Université de Montréal.

E. Ghysels and P. Perron (1992), "The Effect of Seasonal Adjustment Filters on Tests for a Unit Root," Journal of Economotrics (forthcoming).

C.W.J. Granger and P.L. Siklos (1992), Temporal Aggregation, Seasonal Adjustment, and Cointegration: Theory and Evidence", manuscript, Wilfrid Laurier University.
A. Hall (1990), Testing for a Unit Root in Time Series with Pretest Data Based Model Selection," Discussion Paper, Dept. of Economics, N.C.S.U.

L.P. Hansen and T.J. Sargent (1992), "Seasonality and Approximation Errors in Rational Expectations Models," Journal of Econometrics (forthcoming).

S. Hylleberg, C. Jorgensen, and N.K. Sorensen (1992), 'Aggregation and Seasonal Unit Roots: A Note, "Institute of Economics, University of Aarhus (mimeo).

S. Hylleberg. R.F. Engle, C.W.J. Granger, and H.S. Lee (1992), "Seasonal Cointegration: The Japanese Consumption Function," Journal of Econometrics (forthcoming).

S. Hylleberg (1986), Seasonality In Regression, (Academic Press, New York.)

H.S. Lee and P.L. Siklos (1991a), Unit Roots and Seasonal Unit Roots in Macroeconomic Time Series: Canadian Evidence." Economics Letters, 35, 27377.

H.S. Lee and P.L Siklos (1991b). The Influence of Seasonal Adjustment on Unit Roots and Cointegration: Canadian Consumption Function, 1947-91," manuscript, Wilfrid Laurier University.

H.S. Lee and P.L. Siklos (1991C). "The Seasonal Cycle and the Business Cycle: MoneyIncome Correlations in U.S. Data Revisited," manuscript, Wilfrid Laurier University.

C. Nelson and H. Kang (1981), "Spurious Periodicity in Inappropriately Detrended Time Series," Econometrica, 49, 741-57.

M. Nerlove et al. (1979), Analysis of Economic Time Series - A Synthesis (Academic Press, New York).

D.R. Osbom (1990), "A Survey of Seasonality in UK Macroeconomic Variables", International Journal of Forecasting, 6, 227-36.

D. Otto and T. Wirjanto (1991), "Dynamic Adjustment of the Demand for Money for Canada," working paper no. 9114, University of Waterloo.

V.A. Ramey (1989), "Inventories as Factors of Production and Economic Fluctuations," American Economic Review, 79 (June), 338-54.

C.A. Sims (1974), "Seasonality in Regression", Joumal of the American Statistical Association, 69, 618-26.

C.A. Sims (1985), "Comment on 'Issues Involved with the Seasonal Adjustment of Economic Time Series' by William R. Bell and Steven C. Hiltmer,' Journal of Business and Economic Statistics, 3 (January), 92-4. 
C.A. Sims (1992), "Rational Expectations Modeling with Seasonally Adjusted Data," Journal of Econometrics (forthcoming).

K.F. Wallis (1974). "Seasonal Adjustment and Relations Betwoen Variables," Joumal of the American Statistical Ascociation, 69, 18-32.
APPENDIX

\section{Proof of Theorem 3.}

Proof of Theorem 3.1:

We concentrate our proof on the case of $t_{1}$ as the arguments for $t_{2}$ through $t_{4}$ are similar. Ghysels, Lee and Noh (1991), henceforth denoted GLN (1991), show there is a finite sample as well as an asymptotic equivalence between the HEGY $t_{1}$ statistic, for fixed and finite $)$, and the ADF $1-$ statistic with a $(j+3)$ AR polynomial expansion. To discuss the equivalence we shall first make abstraction of the fact that a trend and seasonal dummies appear in equation (3.1). Consider, first, the DGP as described by (3.2) and (3.3). Then GLN show that the regression equation

$$
\Delta x_{t}=\phi_{1} x_{t-1}+\phi_{2} \Delta x_{t-1}+\phi_{3} \Delta x_{t-2}+\phi_{4} \Delta x_{t-3}+\mu_{t}
$$

where $\phi_{1}=\alpha-1$, while $\phi_{1}=-\alpha$ for $i=2, \ldots, 4$, yields a t statistic for $\phi_{1}$ whose finite sample and asymptotic distribution is the same as that of the HEGY $t_{10}$ test. Naturally, this equation corresponds to that of an ADF regression with an AR(3) expansion. This equivalence can be extended to HEGY procedures with $j A R$ lags for $j=1, \ldots, J<\infty$, and also to HEGY procedures which include a trend and/or seasonal dummies. In the latter case, as Dickey, Bell and Miller (1986) show, one consults the DF distribution for a test statistic with a constant in the ADF regression equation. With this correspondence between HEGY $h_{4}$ and ADF with a $(j+3)$ expansion being established we can rely on the theoretical results in Hall (1990a, b). In particular, assumption 2.2 still holds with the transformation showing the equivalence between HEGY and ADF, namely $(1)\left(\dot{p}_{T}+3\right)$ $\left(p_{0}+3\right) \stackrel{P}{\rightarrow} O,(2)$ the distribution of $\dot{p}_{T}+3$ is still independent of the $t$ statistic and $(3) \Pi\left(\dot{p}_{T}\right.$ $\left.+3<p_{0}+3\right)=0$ also holds. Then applying theorem 2.1 and corollary 2.1 in Hall (1990) yields the result for the $t_{1 j}$ statistic. An argument similar in nature also apply to the test statistics $t_{4}$ through $t_{4,}$, see GLN (1991) for further discussion. 
TABLE B1

Autocorrelations and Partial Autocorrelations *

\begin{tabular}{|c|c|c|c|c|c|c|c|c|c|c|c|c|c|c|c|c|c|}
\hline \multirow[b]{3}{*}{ Series } & \multirow[b]{3}{*}{ Transform } & \multicolumn{8}{|c|}{ Aurocorrelations } & \multicolumn{8}{|c|}{ Pertial Awlocorrelations } \\
\hline & & \multicolumn{8}{|c|}{ Lag } & \multicolumn{8}{|c|}{ Lي } \\
\hline & & 1 & 2 & 3 & 4 & 5 & 6 & 7 & 8 & 1 & 2 & 3 & 4 & 3 & 6 & 7 & 8 \\
\hline \multirow[t]{7}{*}{ GNP } & Level & .98 & .96 & .94 & .92 & .90 & .89 & .87 & .85 & .98 & .02 & .02 & $\therefore .01$ & .01 & .00 & -01 & .01 \\
\hline & $\Delta$ & .60 & .34 & .61 & .90 & .63 & .32 & .60 & .66 & -.60 & .05 & .67 . & $: .71$ & -.27 & -.23 &. .11 & .11 \\
\hline & 4 & .83 & .54 & .22 & .06 &. .18 &. .16 & .07 & .04 & .83 & .44 & .26 & .04 & .29 & .05 & .08 & .01 \\
\hline & $\Delta_{m}$ & .37 & .25 & .00 & .10 &. .12 & .06 & .02 & .08 & .37 & .13 & -.15 & -.10 &. .02 & .03 & .01 & -.11 \\
\hline & $\Delta-S D$ & .02 & .003 &. .15 & .38 & .28 & -.13 & -.15 & .31 & -.02 & .004 & -.15 & .38 & .34 & -.12 & -.02 & .13 \\
\hline & $\Delta 4$ & .32 & .12 & -.12 & -.46 & .36 & -.21 & .07 & -.00 & .32 & .02. & .19 & -.42 & -.13 & .02 & .06 & .24 \\
\hline & $(1-L)(1+L)$ & .16 & .70 & .02 & .72 & .06 &. .76 & .02 & 69 & .16 &. .74 & .78 & -.38 & .15 & .15 & .16 & .06 \\
\hline \multirow[t]{7}{*}{ Cons. } & Level & .98 & .97 & .95 & .93 & .92 & .90 & .88 & .86 & .98 & .01 & .01 & .02 & .01 & -.01 & .06 & -.01 \\
\hline & $\Delta$ & .68 & .41 & .67 & .94 & .65 & .39 & .65 & .91 & .68 & -.09 & -.80 & .69 & .15 & .21 & .01 & .26 \\
\hline & $\Delta_{4}$ & .78 & .65 & .50 & .32 & .33 & .30 & .35 & .38 & .78 & .11 &. .11 & .17 & .33 & .05 & .14 & .002 \\
\hline & $\Delta_{m}$ & .05 & .22 & .04 & .03 & .06 & -.12 & .05 &. .18 & .05 & .22 & .03 & .09 & -.08 & .09 & .10 &. .13 \\
\hline & $\triangle$ A.SD & .41 & .30 & .38 & .61 & -.30 & .19 & -.32 & .54 &. .26 & .23 & .32 & .49 &. .22 & .16 & .27 & 50 \\
\hline & $\Delta \mathbf{A}$ & .22 & .13 & .03 &. .43 & .11 & .21 & .08 & -.02 & .22 & .09 & .08 &. .45 & .09 & -.11 & .03 & -.22 \\
\hline & $(1-L)(1+L)$ & .07 &. .85 & .02 & .89 & .03 & .83 & .01 & .86 & .07 &. .86 & .74 & .04 & .08 & -.10 & .30 & .07 \\
\hline \multirow[t]{7}{*}{ Cons Durables } & Level & .98 & .96 & .94 & .92 & .90 & .88 & .86 & .84 & .98 & -.02 & .02 & 03 & .02 & .01 & .00 & .01 \\
\hline & $\Delta$ &. .73 & .57 &. .72 & .86 & .70 & .52 & .68 & .83 & .73 & .09 & .60 & .55 & .04 & -.27 & -.12 & .23 \\
\hline & $\Delta$ & .64 & .38 & .09 & .19 & .20 & .21 &. .13 & -.02 & .64 & .05 & .23 & .26 & .18 & -.05 & .001 & .003 \\
\hline & $\Delta_{n n}$ & .10 & .13 & -.11 & .02 & .03 & .06 & .04 &. .16 &. .10 & .12 & -.09 & .06 & .05 & .06 & .06 &. .16 \\
\hline & $\Delta$-SD & .22 & .16 & .20 & .19 &. .14 & .02 & .09 & .10 &. .22 & .12 & -.15 & .11 & -.05 & -.12 & .06 & .05 \\
\hline & $\Delta \mathbf{A}_{\mathbf{u}}$ &. .11 & .12 & .01 &. .42 & .01 & .16 & .01 & .01 &. .11 & .10 & .01 &. .45 & -.10 & -.08 & .03 &. .22 \\
\hline & $(1-L)(1+L)$ & .18 &. .63 & .02 & .59 &. .03 &. .65 & .02 & .59 & .18 & .68 & .56 & .07 & .22 & -.21 & .24 & .04 \\
\hline
\end{tabular}


TABLE BI (continued)

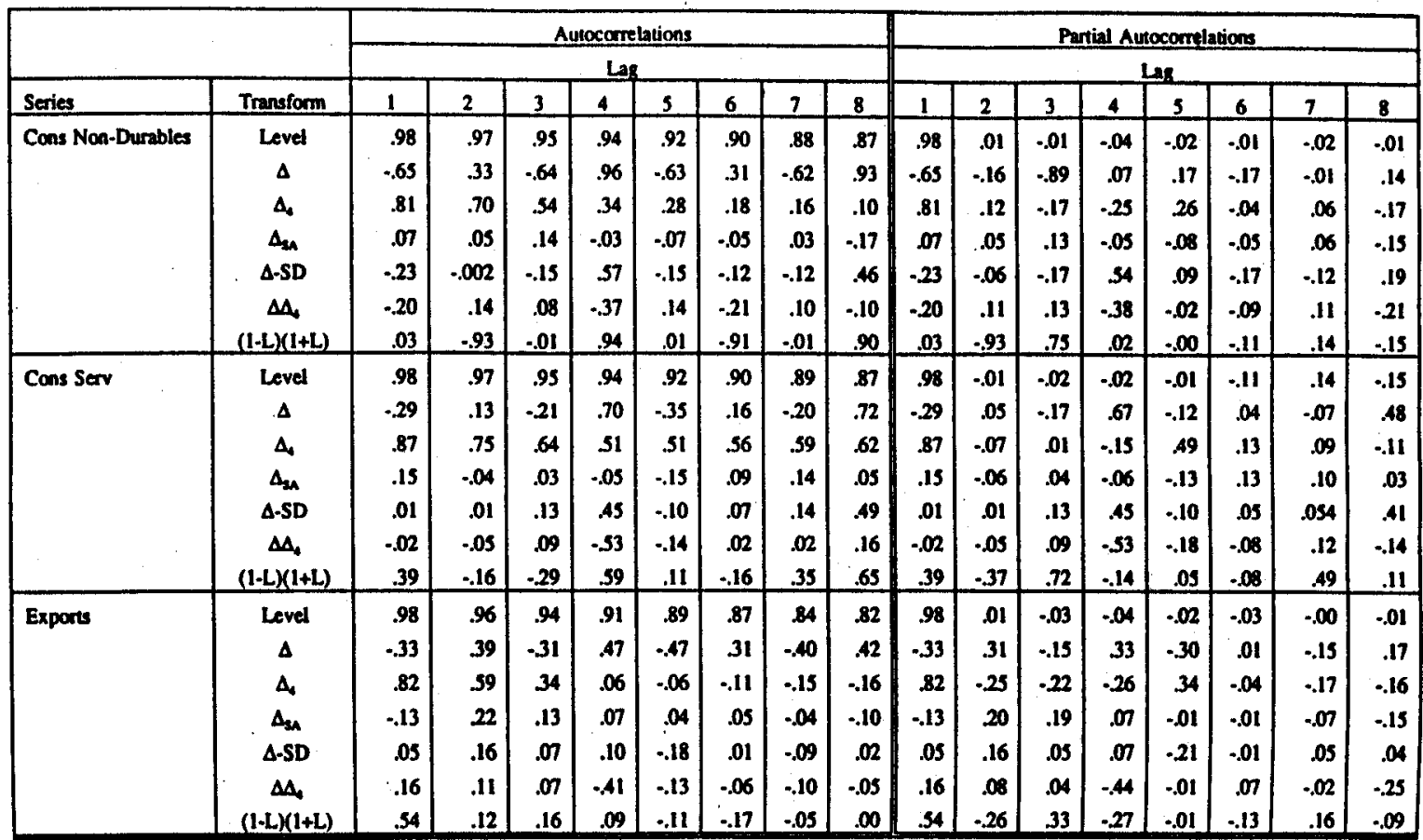

TABLE BI (continued)

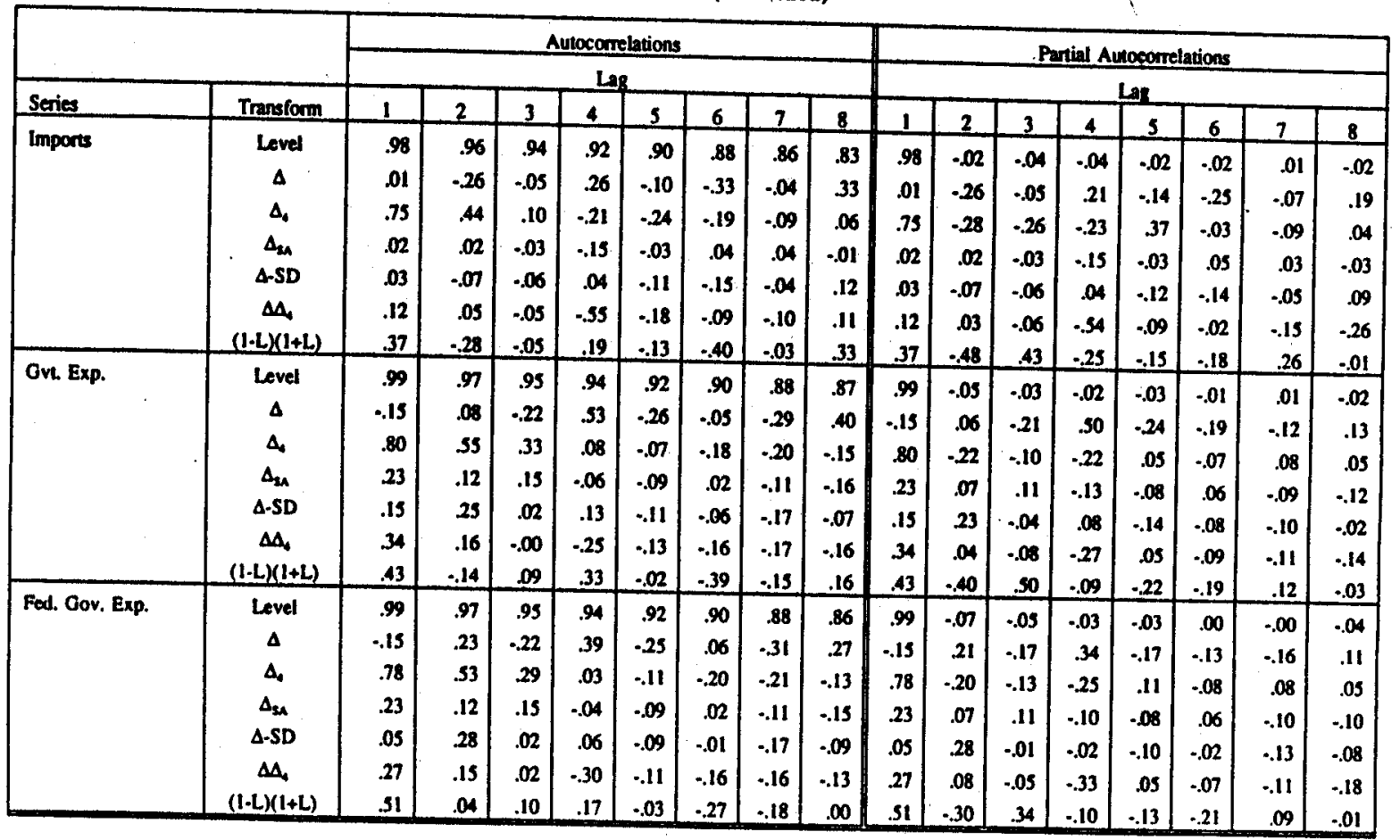


TABLE BI (continued)

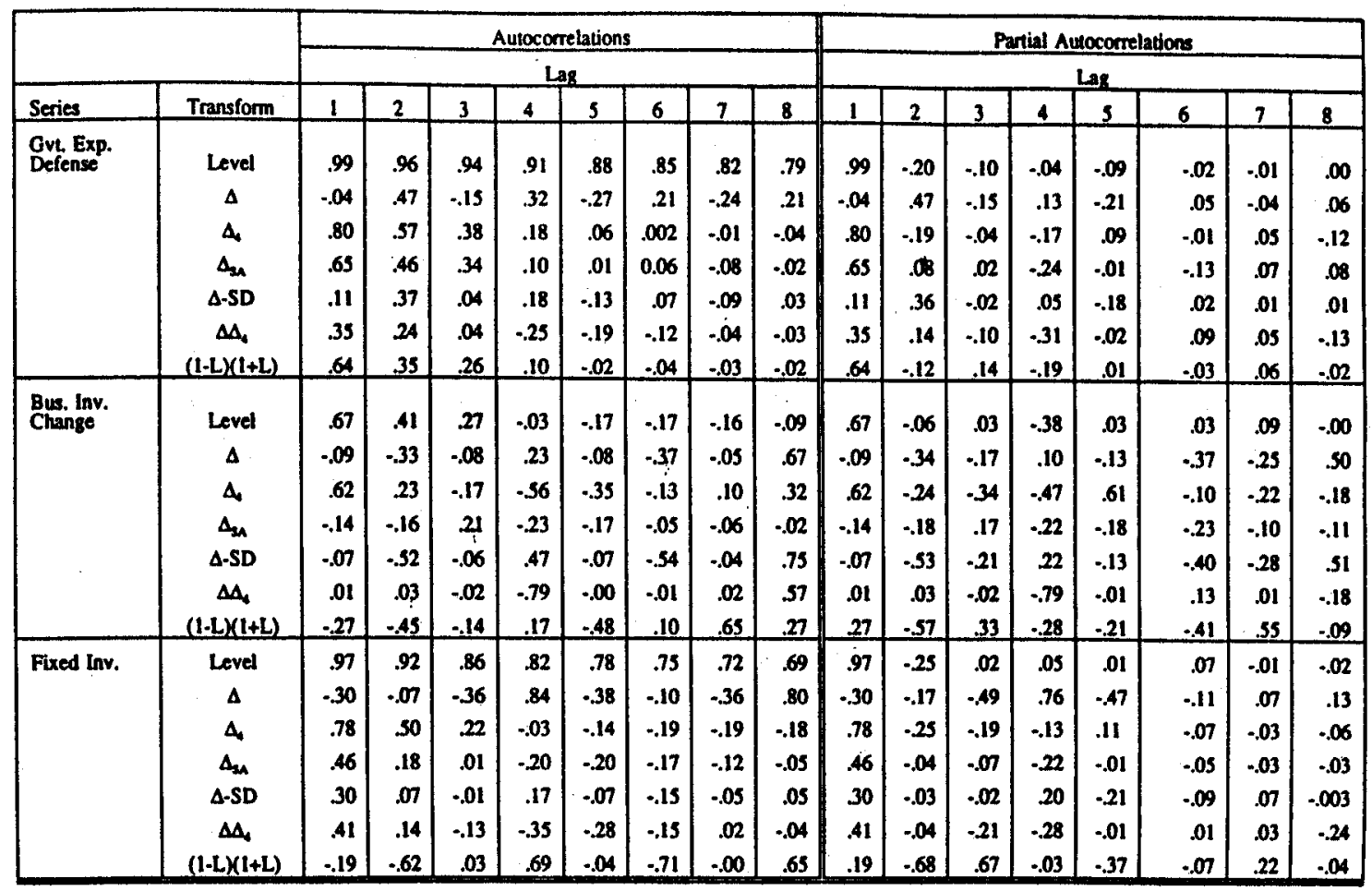

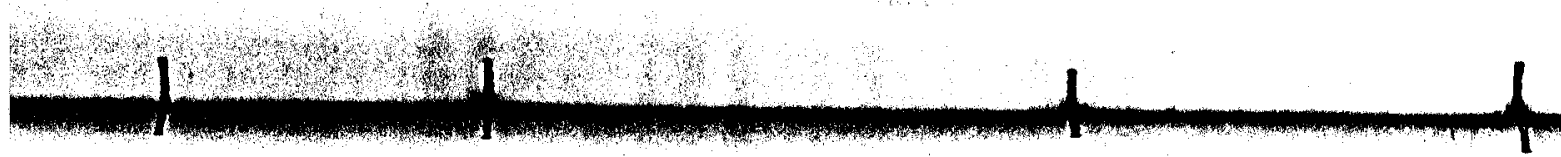

TABLE B1 (continued)

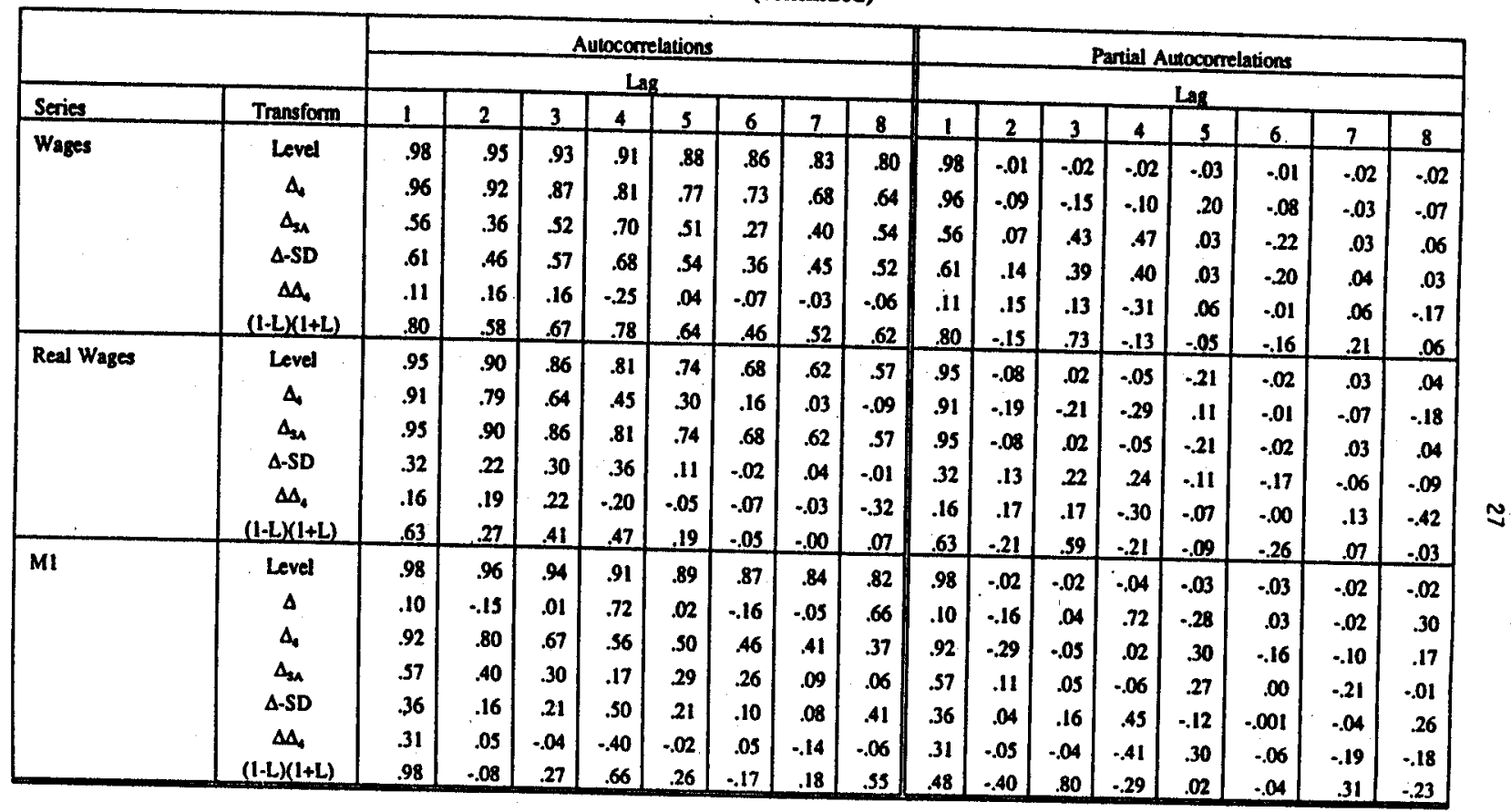


TABLE BI (continued)

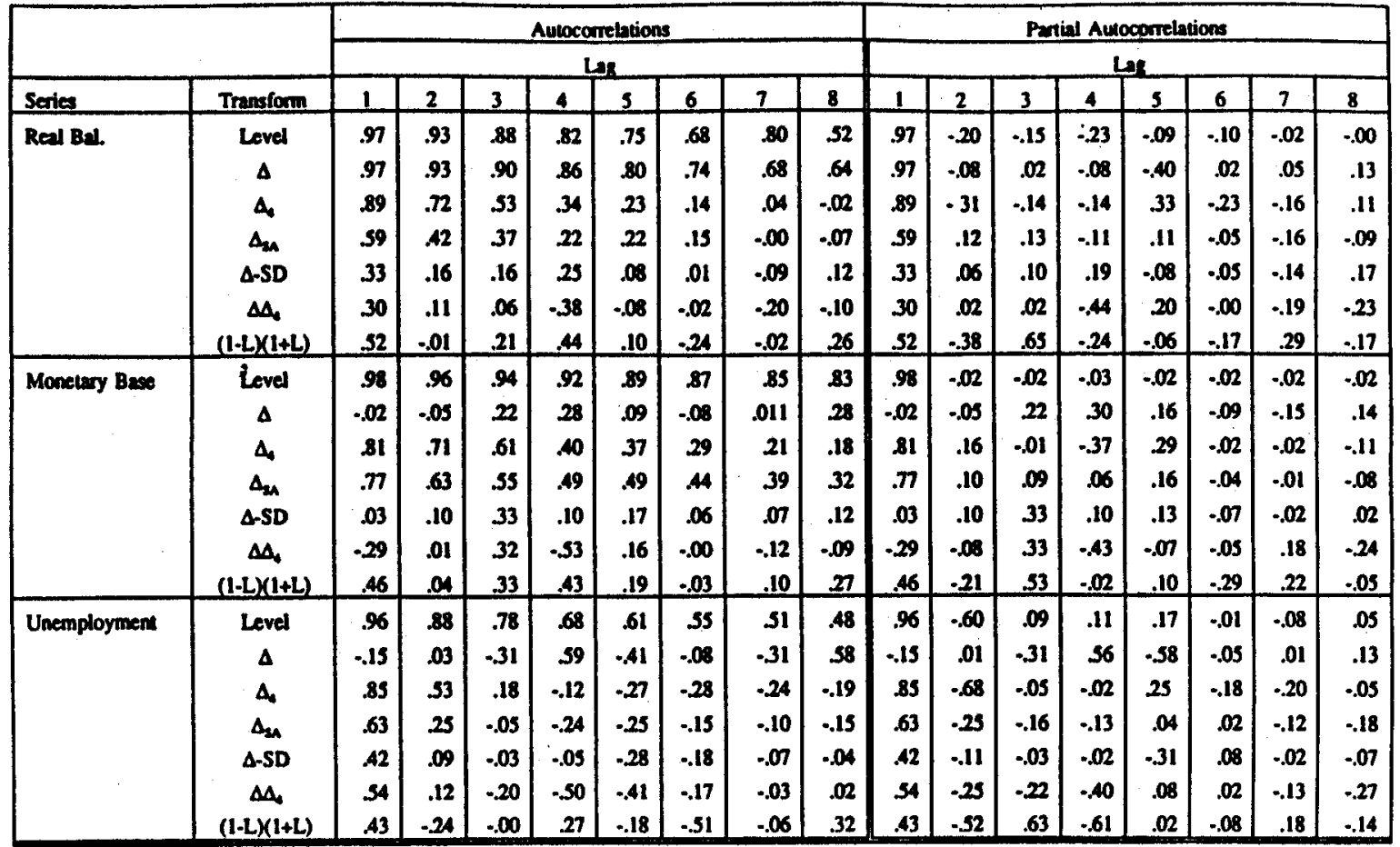

TABLE BI (continued)

\begin{tabular}{|c|c|c|c|c|c|c|c|c|c|c|c|c|c|c|c|c|c|}
\hline \multirow[b]{3}{*}{ Series } & \multirow[b]{3}{*}{ Transfom } & \multicolumn{8}{|c|}{ Autocorrelations } & \multicolumn{8}{|c|}{ Partial Ausocomelations } \\
\hline & & \multicolumn{8}{|c|}{ Lag } & \multicolumn{8}{|c|}{ Las } \\
\hline & & 1 & 2 & 3 & 4 & 5 & 6 & 7 & 8 & 1 & 2 & 3 & 4 & 5 & 6 & 7 & 8 \\
\hline \multirow[t]{7}{*}{ Employment } & Level & .98 & .96 & .94 & .92 & .90 & .88 & .86 & .84 & .98 & .00 & .00 & .02 & .00 & -.01 & -.01 & .01 \\
\hline & $\Delta$ &. .04 & $\cdot .54$ &. .11 & .74 &. .14 &. .55 & -.13 & .70 & -.04 & .54 &. .22 & .62 & -.42 &. .12 & -.13 & .20 \\
\hline & 4 & .83 & 52 & .20 & -.09 & .21 & .26 & .27 & -.24 & .83 & .51 & -.14 &. .12 & .25 & .24 & .09 & -.01 \\
\hline & $\Delta_{\text {sA }}$ & .49 & .22 & .07 & -.06 & $\cdot .17$ & -.13 &. .10 & -.14 & .49 & -.03 & .03 &. .10 &. .12 & .03 & .02 & -.12 \\
\hline & $\Delta-S D$ & 23 & -.08 &. .08 & .16 & -.11 & -.17 &. .19 & .06 & .23 &. .14 & .03 & .19 &. .23 & .07 &. .14 & .07 \\
\hline & $\Delta \mathbf{A}_{\mathbf{A}}$ & 39 & .06 & -.11 & -.44 & .25 & -.12 &. .13 & -.09 & .39 &. .11 & -.12 &. .41 & .09 & .08 & -.16 & -.25 \\
\hline & $(1-L)(1+L)$ & 20 &. .63 & .01 & .63 & .05 &. .71 & .05 & .59 & .20 & -.70 & .71 & .40 &. .15 & -.12 & .17 &. .14 \\
\hline \multirow{7}{*}{ Avg. Hours } & Level & .88 & .70 & .51 & .32 & .19 & .11 & .08 & .06 & .88 &. .32 &. .11 & .09 & .09 & .07 & .08 & -.11 \\
\hline & $\Delta$ & .01 & .69 & .02 & .71 & .03 &. .68 & .01 & .67 & .01 & .69 & .06 & .45 & .04 & .22 & .06 & .17 \\
\hline & $\Delta$ & .78 & $A 7$ & .14 & -.12 &. .20 &. .26 & .30 & .28 & .78 &. .36 & -.21 & .08 & .17 &. .26 &. .15 & .08 \\
\hline & $\Delta_{\text {sn }}$ & .24 & .05 & .03 & .21 & .24 & -.22 & .03 & $\cdot .16$ & .24 & .00 & .05 & .20 &. .16 & .15 & .05 & .23 \\
\hline & $\Delta-S D$ & .05 & .04 & .20 & .12 &. .10 & .01 & .19 & .05 & .05 & .04 & .20 & .15 &. .11 & .03 &. .14 & -.09 \\
\hline & $\Delta \mathbf{A}_{\mathbf{q}}$ & .04 & -.01 & .05 &. .45 & .06 & .00 & .01 & .09 & .04 & .01 & .05 &. .45 & .02 & .02 & .05 & -37 \\
\hline & $(1-L)(1+L)$ & .15 &. .68 & .03 & .71 & .01 &. .68 & .01 & .66 & .15 &. .72 & .68 &. .13 &. .11 &. .19 & .23 & .03 \\
\hline \multirow[t]{7}{*}{ Labor Force } & Level & .99 & .97 & .95 & .94 & .92 & .91 & .89 & .88 & .99 & .01 & .01 & .02 & .01 & .01 & .00 & -.01 \\
\hline & $\Delta$ & -.02 & -.82 & -.04 & .90 & .02 & -.79 & .04 & .86 & .02 & .82 & .28 & .67 & -.17 & .03 &. .00 & .18 \\
\hline & $\Delta$ & .84 & .67 & .51 & .36 & .32 & .28 & .26 & 28 & .84 &. .13 & .07 & .06 & .26 & .06 & .04 & .12 \\
\hline & $\Delta_{\text {an }}$ & .09 & .06 & .03 & .19 & .17 & .08 & .01 & .00 & .09 & .05 & .02 & .18 & .15 & .04 & -.04 & .04 \\
\hline & $\Delta \cdot S D$ & .10 &. .03 &. .18 & 52 & .07 & .02 & .20 & .36 & -.10 & .04 & .19 & .50 & .04 & .03 & .06 & 13 \\
\hline & $\Delta \mathbf{A}_{\mathbf{A}}$ & .04 & .04 & .04 &. .33 & .02 & .06 & .13 & .10 & .04 & .04 & .03 & .33 & $m$ & & & to \\
\hline & $(1-L)(1+L)$ & .06 & -.88 & .01 & .90 & .02 & .84 & .01 & .85 & .08 &. .88 & .69 & .10 & .00 & -.10 & -.16 & .25 \\
\hline
\end{tabular}


TABLE B1 (continued)

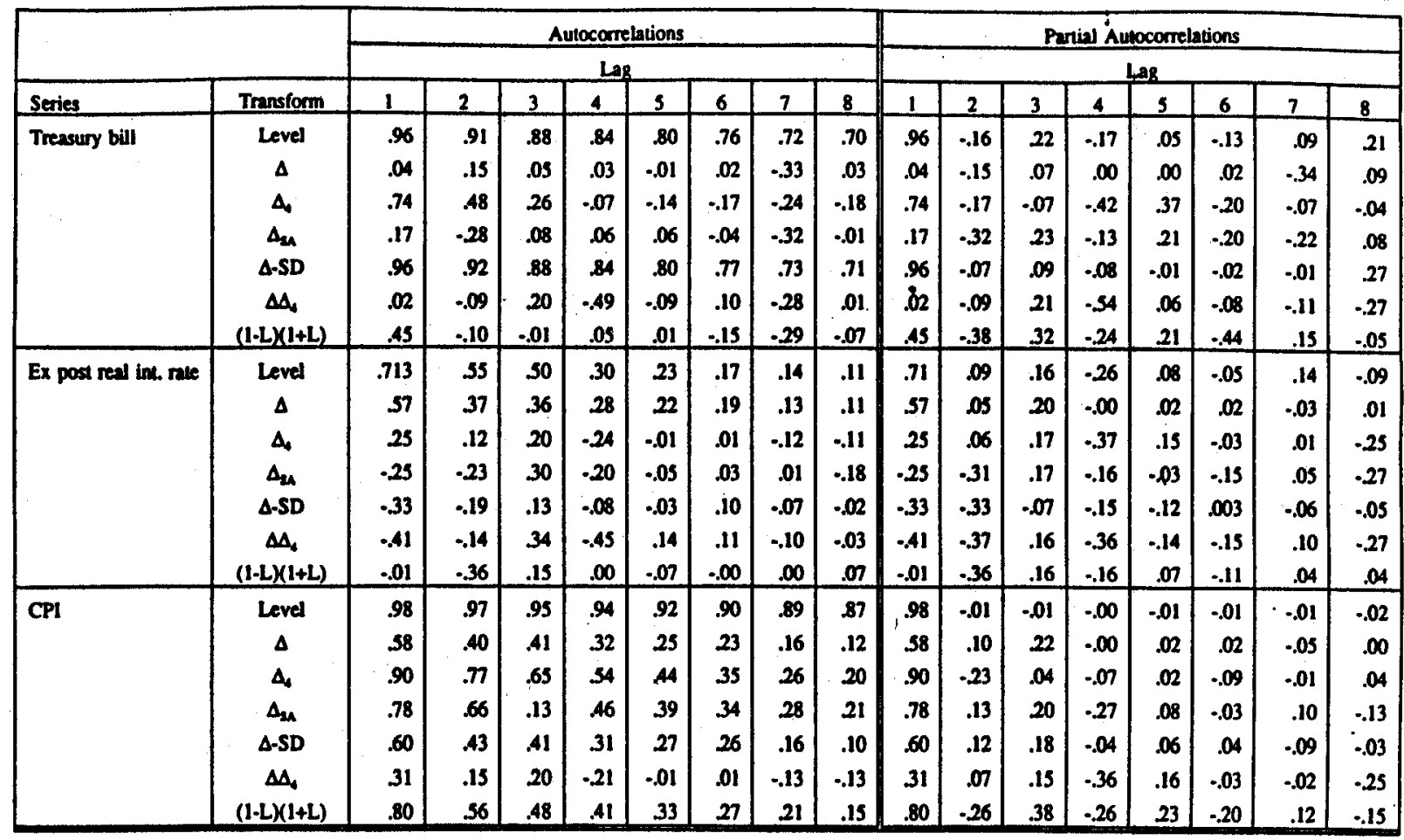

All series are seasonally unadjusted except for the $\Delta_{\text {sh }}$ filter which relies on seasonally adjusted data at the source. All series are in logarithms of the levels except for the change in business inventories, the unemployment rate, treasury bill rate, and ex post real interest rate, which are in levels.

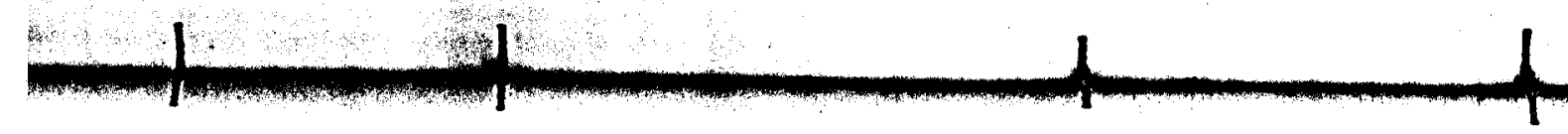

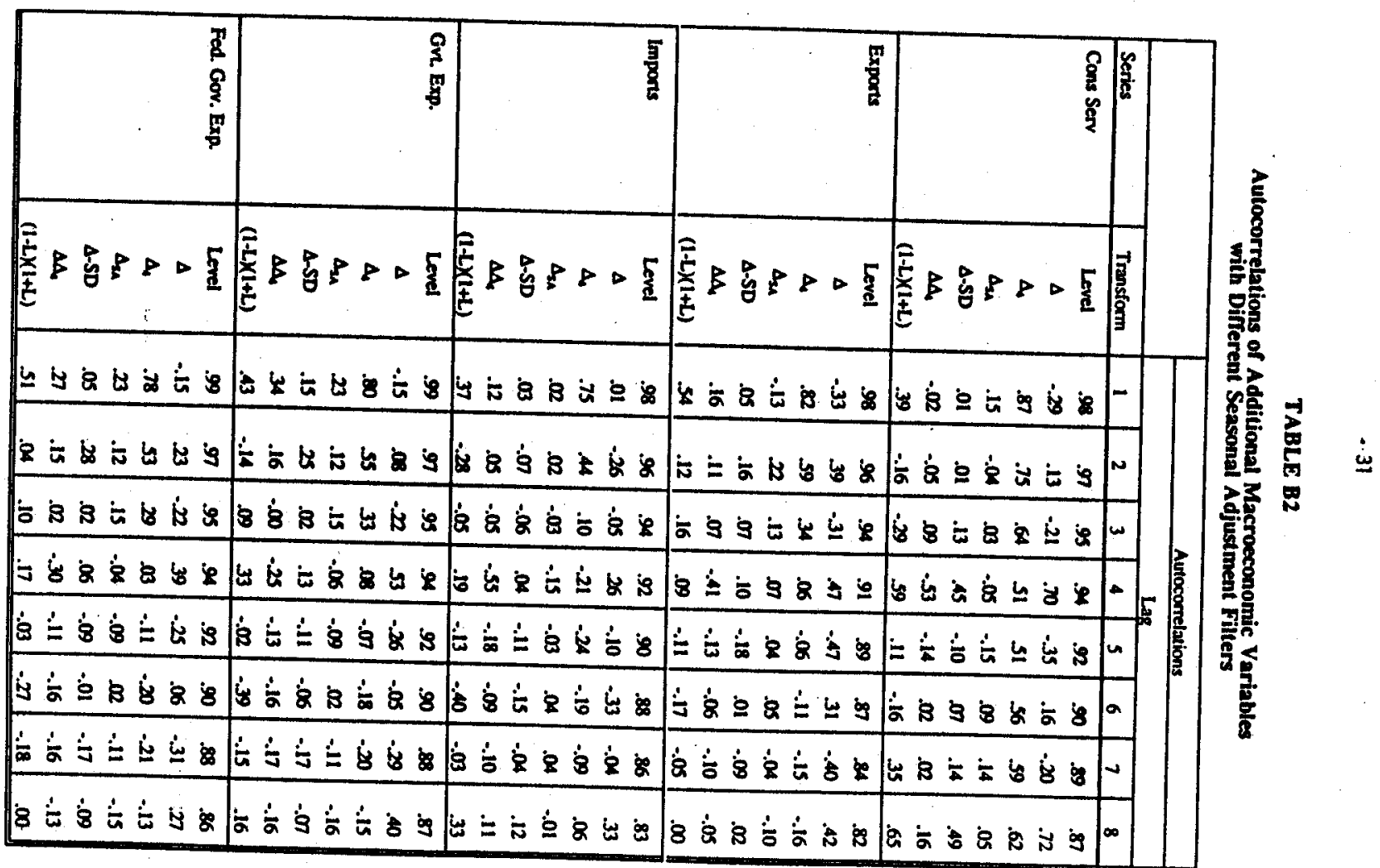


TABLE B2 (continued)

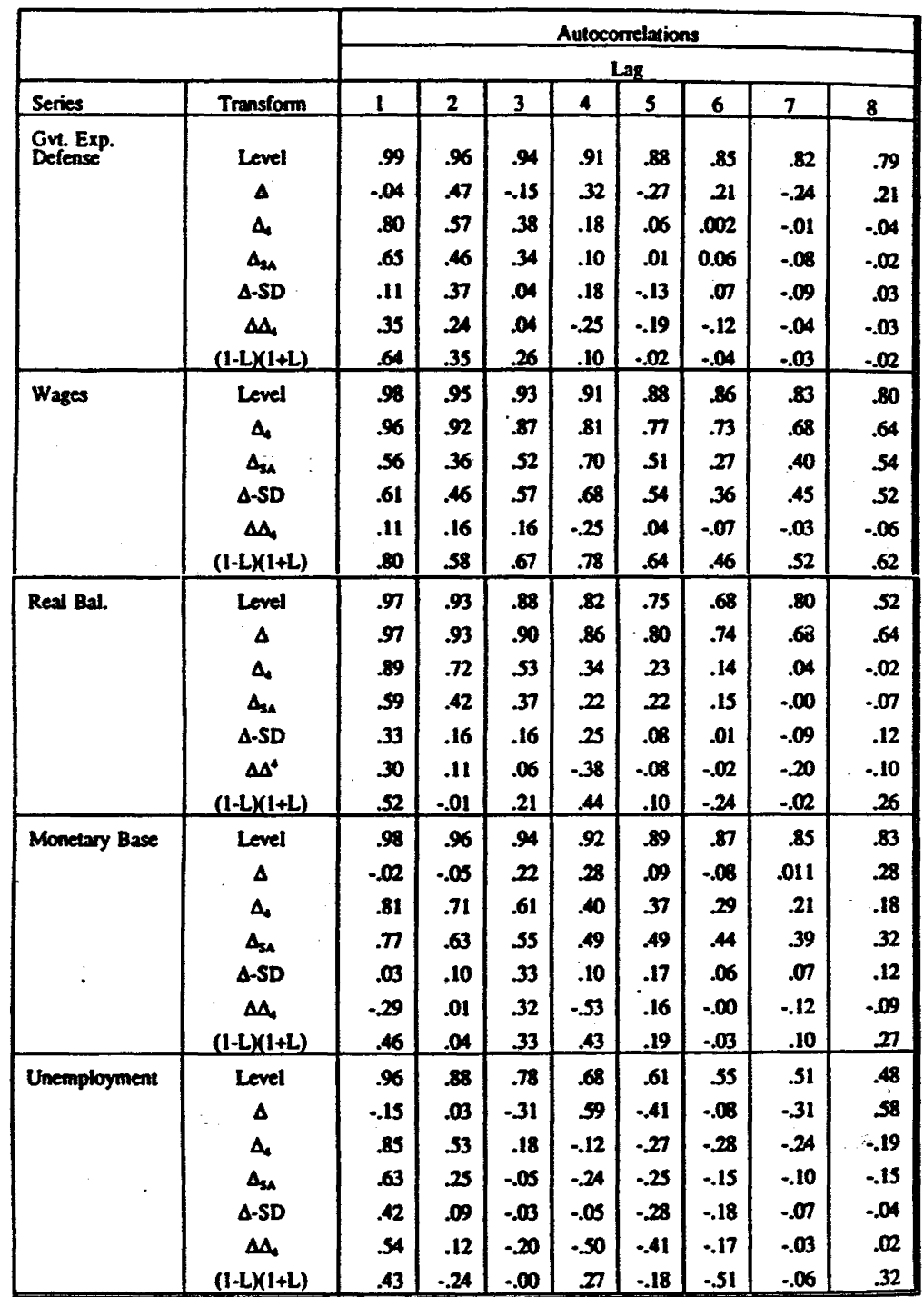

TABLE B2 (continued)

\begin{tabular}{|c|c|c|c|c|c|c|c|c|c|}
\hline \multirow{4}{*}{ Series } & \multirow{4}{*}{ Tronsform } & \\
\hline & & \multirow{2}{*}{\multicolumn{8}{|c|}{$\begin{array}{l}\text { Autocorrelations } \\
\text { Lag }\end{array}$}} \\
\hline & & & & & & & & & \\
\hline & & 1 & 2 & 3 & 4 & 5 & 6 & 7 & 8 \\
\hline \multirow{7}{*}{ Employment } & Level & .98 & .96 & .94 & .92 & .90 & .88 & .86 & .84 \\
\hline & $\Delta$ & .04 &. .54 & -.11 & .74 & -.14 & -.55 &. .13 & .70 \\
\hline & 4 & .83 & .52 & .20 & .09 & -.21 & .26 & .27 & -.24 \\
\hline & $\Delta_{\text {su }}$ & .49 & 22 & .07 & .06 & -.17 & -.13 & -.10 & -.14 \\
\hline & $\triangle$-SD & .23 & -.08 & -.08 & .16 & -.11 & -.17 & -19 & .06 \\
\hline & $\Delta \mathbf{4}$ & .39 & .06 & -.11 &. .44 &. .25 &. .12 & -.13 & -.09 \\
\hline & $(1+L)(1+L)$ & 20. &. .63 & -.01 & .63 & .05 & .71 & .05 & .59 \\
\hline \multirow{7}{*}{ Labor Fance } & Level & .99 & 97 & .95 & .94 & .92 & .91 & .89 & .88 \\
\hline & $\Delta$ & -.02 &. .82 & -.04 & .90 & -.02 & .79 & .04 & .86 \\
\hline & 4 & 84 & .67 & .51 & .36 & .32 & .28 & .26 & .28 \\
\hline & $\Delta_{\text {su }}$ & .09 & .06 & .03 & .19 & .17 & .08 & .01 & .00 \\
\hline & $\Delta-S D$ & -.10 & .03 & -.18 & .52 & -.07 & .02 & .20 & .36 \\
\hline & $\mathbf{A 4}$ & .04 & .04 & .04 & -.33 & .02 & -.06 & -.13 & -10 \\
\hline & $(1-L)(1+L)$ & .06 &. .88 & .01 & .90 & .02 &. .84 & .01 & .85 \\
\hline \multirow[t]{7}{*}{ Treasury bill } & Level & .96 & .91 & .88 & .84 & .80 & .76 & .72 & .70 \\
\hline & $\Delta$ & .04 & .15 & .05 & .03 & -.01 &.$\infty$ & .33 & .03 \\
\hline & 4 & .74 & .48 & .26 & -.07 & -.14 &. .17 & .24 & -18 \\
\hline & $\Delta_{2 n}$ & .17 & -.28 & .08 & .06 & .06 & -.04 & .32 & .01 \\
\hline & $\triangle$-SD & .96 & .92 & .88 & .84 & .80 & $\pi$ & .73 & .71 \\
\hline & $\Delta 4$ & .02 & .09 & .20 & -.49 & .09 & .10 & -.28 & .01 \\
\hline & $(1-L)(1+L)$ & 45 & .10 & .01 & .05 & .01 & -.15 & .29 & -.07 \\
\hline \multirow{7}{*}{ Ex post real int rate } & Level & .713 & .55 & .50 & .30 & 23 & .17 & .14 & .11 \\
\hline & $\Delta$ & 57 & .37 & .36 & .23 & .22 & .19 & .13 & .11 \\
\hline & 4 & 25 & .12 & .20 & -.24 & .01 & .01 &. .12 & -.11 \\
\hline & $\Delta_{\text {an }}$ & -.25 & .23 & 30 & -.20 & .05 & .03 & .01 & -.18 \\
\hline & $\Delta-S D$ & .33 & -.19 & .13 & -.08 & -.03 & .10 & -.07 & -.02 \\
\hline & $\Delta 4$ & -.41 &. .14 & .34 &. .45 & .14 & .11 & -.10 & .03 \\
\hline & $(1-L \times(1+L)$ & -.01 & -.36 & .15 & .00 & -.07 & .00 & .00 & .07 \\
\hline \multirow[t]{7}{*}{ CPI } & Level. & .98 & .97 & 95 & .94 & .92 & .90 & .89 & .87 \\
\hline & $\Delta$ & .58 & .40 & .41 & 32 & .25 & .23 & .16 & .12 \\
\hline & 4 & .90 &.$n$ & .65 & .54 & .4 & .35 & .26 & 20 \\
\hline & $\Delta_{\text {su }}$ & .78 & .66 & .13 & .46 & .39 & .34 & .28 & .21 \\
\hline & $\triangle-S D$ & .60 & .43 & .41. & .31 & .27 & .26 & .16 & .10 \\
\hline & $\Delta$ & .31 & .15 & 20 & -.21 &. .01 & .01 & -.13 & -.13 \\
\hline & $-L \times(1+L)$ & .801 & .56 & .48 & 41 & .33 & .27 & .21 & .15 \\
\hline
\end{tabular}

All series are seasonally unadjosed except for the $\Delta_{n}$ filter which relies on seasonally atjuested data at the source. treasury bill rate, and ex post real interest except for the change in business inventories, the unemployment rale. 
34

TABLE B3

U.S. Unadjusted Quanterly Data from Barsty and Miron: Sample Ends 1948.1 - 1989.4 Seasonal Unit Rook Test Using Selective Augmentation Technique "i"-iest results

\begin{tabular}{|c|c|c|c|c|c|}
\hline \multicolumn{6}{|c|}{ Model includes [I. SD. Tr] } \\
\hline & \multicolumn{4}{|c|}{ Frequencies } & \multirow[b]{2}{*}{ AUC } \\
\hline & $x_{1}$ & $\pi_{2}$ & $x_{3}$ & $\pi_{4}$ & \\
\hline Gross National Product & -1.80 & $-3.62^{*}$ & -3.05 & $.5 .58^{\circ}$ & 1 \\
\hline Per Capita & -2.90 & $-3.39^{\circ}$ & $-3.48 *$ & $-5.57^{\circ}$ & 1 \\
\hline Consumption Exp. & -2.04 & -1.57 & -2.65 & $-2.57^{\circ}$ & 12,45 \\
\hline Durables & -1.81 & $-5.32^{*}$ & $-9.13^{*}$ & $-6.43^{*}$ & - \\
\hline Nondurables & -2.34 & -2.11 & -2.81 & -1.54 & 1.2 .45 \\
\hline Services & -2.01 & -2.72 & $-4.07^{*}$ & -0.28 & 1.4 .5 \\
\hline Per capita & -2.60 & -1.46 & $-4.89 *$ & $-2.59^{*}$ & 1.4 \\
\hline Durables & -3.18 & $-5.64^{*}$ & $-7.29^{*}$ & $-6.99^{*}$ & - \\
\hline Nondurables & $-3.96^{\circ}$ & -284 & $4.50^{\circ}$ & -1.24 & 1. \\
\hline Services & --2.20 & -2.62 & $-4.39^{*}$. & 0.31 & 1.4 .5 \\
\hline Fixed Investment & -2.46 & $-5.11^{*}$ & -2.52 & $-7.38 *$ & 1 \\
\hline $\begin{array}{l}\text { Government Expendi- } \\
\text { tures }\end{array}$ & $4.24^{\circ}$ & $-5.63^{\circ}$ & $-3.81^{\circ}$ & $-8.31^{*}$ & 1 \\
\hline Federal & -2.98 & $-5.52^{*}$ & $-9.64^{\circ}$ & $-10.05^{*}$ & - \\
\hline Defense & -3.25 & $-6.95^{*}$ & $-11.53^{*}$ & $-12.37^{*}$ & - \\
\hline Exports & -3.17 & $-6.15^{*}$ & $-6.58^{*}$ & $-7.10^{*}$ & 1 \\
\hline Imports & -1.43 & $-7.34^{*}$ & $-6.62^{\circ}$ & $-7.90^{\circ}$ & - \\
\hline Change in inventories & $-6.39 *$ & $-5.86^{\circ}$ & $-9.39 *$ & $-7.68 *$ & 2.4 .5 \\
\hline Unemployment & $-3.65^{*}$ & $-6.27^{*}$ & .2 .55 & $-8.78 *$ & 1 \\
\hline Employment & -3.13 & $-5.24^{*}$ & -2.32 & $-6.85 *$ & 1 \\
\hline Average Hours & -1.44 & $4.93^{*}$ & $4.70^{*}$ & $.7 .64^{*}$ & - \\
\hline Labor Force & $-3.74^{*}$ & $.3 .10^{*}$ & .3 .26 & $-4.54^{*}$ & $t$ \\
\hline Price Level & -1.98 & $-9.69^{\circ}$ & $-7.80^{\circ}$ & $-10.23^{*}$ & - \\
\hline Interest Rate & .2 .39 & $-9.02^{*}$ & $-6.96^{*}$ & $-6.20^{*}$ & 4 \\
\hline Ex post real & $-5.39 *$ & $-7.19^{*}$ & $-11.45^{\circ}$ & -1.00 & - \\
\hline Nominal Wage & -2.44 & $-7.27^{\circ}$ & -2.30 & $-4.67^{*}$ & 2 \\
\hline Real Wage & -2.35 & $.7 .31^{\circ}$ & $-5.96^{*}$ & $-4.76^{*}$ & 7 \\
\hline Monetary Base & $4.87^{*}$ & $-7.42^{*}$ & $-8.50^{\circ}$ & $-3.24^{\circ}$ & - \\
\hline Money Supply (MI) & -1.40 & $-3.77^{*}$ & -0.16 & $4.36^{\circ}$ & $1,4.5$ \\
\hline Real Balances & -2.91 & $4.62^{*}$ & -1.88 & $-4.62^{*}$ & $1,4,5$ \\
\hline
\end{tabular}

TABLE BA

U.S. Unadjusted Quarterly Data from Barsky and Miron: Sample Ends 1948.1 - 1989.4 I-value of AR Correction Lag Terms in HEGY Sensonal Unit Rook Tese*

\begin{tabular}{|c|c|c|c|c|c|c|c|c|}
\hline \multicolumn{9}{|c|}{ Modtl include (1, SD. TH } \\
\hline & & & & AR Le Lemeth & & & & \\
\hline Series & 1 & 2 & 3 & 4 & 5 & 6 & 7 & AUG \\
\hline $\begin{array}{l}\text { Grous Netional } \\
\text { Product }\end{array}$ & $5.71(00)$ & $-52(60)$ & sel(12) & t.70109) & $=0(.2)$ & $\cos (50)$ & $.24 .811)$ & 1 \\
\hline Per Copiea & $4.91(.00)$ & $-154.12)$ & . $13(.09)$ & $.124 .22)$ & $.87(38)$ & $.20(.24)$ & $.26(.79)$ & 1 \\
\hline Exp. & $451(.00)$ & $200(00)$ & $.4(66)$ & -3.800 .009 & $2.05(.00)$ & $.004 .93)$ & 1.82(.16) & 1.2 .45 \\
\hline Dendbes & $122(22)$ & $22(n)$ & $-31(.76)$ & $-1.03(31)$ & . & $.04(63)$ & $.74(.46)$ & - \\
\hline Nondernbles & $5.55(100)$ & $200(004)$ & $-1.20(23)$ & $-2.79(01)$ & $2.27(02)$ & $.02(54)$ & $.20(.24)$ & 12.45 \\
\hline Services & $6.60(00)$ & $-1.11(27)$ & $.23(.22)$ & $-3.27(000)$ & $3.00(.00)$ & so(63) & $\operatorname{sen}(56)$ & 1.45 \\
\hline per capino & 5.421 .000 & $.05(.96)$ & $=0(.42)$ & $-234(00)$ & $.72(.4)$ & $.79(.43)$ & $1.81(.07)$ & 1.4 \\
\hline Durables & t.24.0n & $-1.52(.13)$ & $1.19(.23)$ & $-1.56(.12)$ & $.00(.99)$ & $-.60(55)$ & $1.07(.29)$ & - \\
\hline Nonderzbles & $5.90(.00)$ & $.6(51)$ & $.90(.37)$ & $-1.12(24)$ & $1.67(.10)$ & $.04 .96)$ & $.00(.94)$ & 1 \\
\hline Services & $\operatorname{sish}(00)$ & $.56(53)$ & $.70(.46)$ & $-3.29(00)$ & $271(.01)$ & $.00(.96)$ & $1.29(.20)$ & 1.45 \\
\hline Goven & $381(.00)$ & $\cos (50)$ & $201(.04)$ & $1.91(.06)$ & $-1.24(.00)$ & $1.20(23)$ & $.75(.45)$ & 1 \\
\hline Expenditurese & $261(.01)$ & $-.08(.98)$ & $-30.77)$ & $.94(35)$ & $.66(.51)$ & $-.35(.73)$ & $.96(.34)$ & 1 \\
\hline Podered & $.13(.90)$ & $.54(56)$ & $1.48(.14)$ & $.34(.74)$ & $-.74(.46)$ & $-87(38)$ & $226(.02)$ & - \\
\hline Defense & $29.77)$ & $.00(.43)$ & $1.03(30)$ & $.00(.42)$ & . $.19(.85)$ & $.9(32)$ & $-.16(.87)$ & - \\
\hline Exporse & 2284.01) & $-1.10(27)$ & $.97(33)$ & $.54(56)$ & $1.60(.11)$ & $.12(.90)$ & $-1.54(.12)$ & 1 \\
\hline Imports & $1.45(.19)$ & $53(59)$ & $.122(22)$ & $-99(.32)$ & $.32(.75)$ & $\operatorname{tos}(29)$ & $.66(39)$ & - \\
\hline 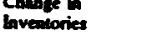 & $.23(.82)$ & $-2.16(.03)$ & $1.91(.06)$ & $.225(103)$ & 2.39(.02) & $.69(.49)$ & $.53(.60)$ & 2.45 \\
\hline Unemployment & 2.49(.01) & $-1.74(00)$ & $21(2)$ & $.21(23)$ & $.29(.78)$ & $.62(-50)$ & $.63(.53)$ & 1 \\
\hline Employment & $3.16(.00)$ & $-8.14(25)$ & $.56(.58)$ & $-1.49(.14)$ & $.74(.46)$ & . $15(.25)$ & $.91(.36)$ & 1 \\
\hline Averne Houns & $1.324 .19)$ & $.93(-.36)$ & $61(54)$ & $.75(.46)$ & $.60(55)$ & $-1.01(.32)$ & $-.15(.88)$ & - \\
\hline Labor Forese & $326(-0)$ & $.57(57)$ & $1.20(.23)$ & $-1.67(09)$ & $.37(.09)$ & $-56(58)$ & $.68(.49)$ & 1 \\
\hline Price Leved & $-.04(.40)$ & $-1.02(31)$ & $.4(-65)$ & $.82(.41)$ & .448.63) & $-.30(.77)$ & $.35(.73)$ & - \\
\hline Interese Rete & $91(36)$ & $.73(.47)$ & $3.45(.00)$ & $-3.61(100)$ & .69.(49) & $-.23(.22)$ & $1.23(.22)$ & 1 \\
\hline Ex poes real & $53(.60)$ & .4n(6) & $\operatorname{sen}(59)$ & $24.81)$ & $-.35(.72)$ & $.60(.65)$ & $.00(.55)$ & - \\
\hline Nomined Wage & $36(.72)$ & $23 \times(-2)$ & $-1.42(.16)$ & $.033(.96)$ & $\therefore .05(.40)$ & $1.36(.189$ & $.052(.96)$ & 2 \\
\hline Real Whase & .99(.63) & $1.22(0 n)$ & $-1.24 .07)$ & $\sec (58)$ & $.99(.33)$ & $1.70(.00)$ & $-1.99(.05)$ & 7 \\
\hline Monetary Bewe & $-.31(.75)$ & $1.0 \times 25)$ & $-55(-58)$ & $.23(.82)$ & - $-12(.90)$ & $36(.72)$ & $-55(58)$ & - \\
\hline M1) & $6.10(.00)$ & $-1.44(.19)$ & se(s6) & $-3.65(.00)$ & $4.12(.00)$ & $-1.03(30)$ & $-1.19(.24)$ & 1.45 \\
\hline Real & 2:00(.01) & $.43(-57)$ & ox (37) & $-2.65(.01)$ & $2.12(.03)$ & $-34(.73)$ & $.24 .81)$ & 1.45 \\
\hline
\end{tabular}


36

TABLE BS

Seasonal Unit Root Test Results: HEGY Method Sample Ends 1985.4

\begin{tabular}{|c|c|c|c|c|c|c|c|}
\hline \multirow[b]{2}{*}{ Series } & \multicolumn{2}{|c|}{ Lag Selection } & \multicolumn{5}{|c|}{ Coefficients in (3.1) } \\
\hline & Criterion & [lags] & $\pi_{1}$ & $\boldsymbol{\pi}_{\mathbf{2}}$ & $\pi$ & $\pi_{4}$ & $\pi_{3} \cap \pi_{4}$ \\
\hline GNP & $\begin{array}{l}\text { I. AIC } \\
\text { II. SC } \\
\text { III. Augmentation } \\
\text { IV. Longest sig. lag }\end{array}$ & $\begin{array}{l}{[5]} \\
{[3]} \\
\text { [II } \\
\text { [II }\end{array}$ & $\begin{array}{l}1 \\
1 \\
1 \\
1\end{array}$ & $\begin{array}{l}1 \\
1 \\
0 \\
0\end{array}$ & $\begin{array}{l}1 \\
0 \\
1 \\
1\end{array}$ & $\begin{array}{l}0 \\
0 \\
0 \\
0\end{array}$ & $\begin{array}{l}\mathbf{0} \\
\mathbf{0} \\
0 \\
0\end{array}$ \\
\hline GNP per capita & II & $\begin{array}{l}\text { [2] } \\
\text { [2] } \\
\text { [1] } \\
\text { [1] }\end{array}$ & $\begin{array}{l}1 \\
1 \\
1 \\
1 \\
\end{array}$ & $\begin{array}{l}1 \\
1 \\
0 \\
0 \\
\end{array}$ & $\begin{array}{l}0 \\
0 \\
1 \\
1 \\
\end{array}$ & $\begin{array}{l}\mathbf{0} \\
\mathbf{0} \\
0 \\
0\end{array}$ & $\begin{array}{l}0 \\
0 \\
0 \\
0 \\
\end{array}$ \\
\hline Consumption & II & $\begin{array}{c}{[0]} \\
{[0]} \\
{[1,2,4,5]} \\
{[5]}\end{array}$ & $\begin{array}{l}1 \\
1 \\
1 \\
1\end{array}$ & $\begin{array}{l}0 \\
0 \\
1 \\
1\end{array}$ & $\begin{array}{l}0 \\
0 \\
0 \\
1\end{array}$ & $\begin{array}{l}0 \\
0 \\
0 \\
1\end{array}$ & $\begin{array}{l}0 \\
0 \\
0 \\
1\end{array}$ \\
\hline Consumption per capita & $\underset{\text { II }}{\text { II }}$ & $\begin{array}{c}{[5]} \\
{[5]} \\
{[1,4]} \\
{[4]} \\
\end{array}$ & $\begin{array}{l}1 \\
1 \\
1 \\
1 \\
\end{array}$ & $\begin{array}{l}1 \\
1 \\
1 \\
1 \\
\end{array}$ & $\begin{array}{l}1 \\
1 \\
0 \\
0 \\
\end{array}$ & $\begin{array}{l}0 \\
0 \\
0 \\
0 \\
\end{array}$ & $\begin{array}{l}\mathbf{0} \\
0 \\
\mathbf{0} \\
\mathbf{0} \\
\end{array}$ \\
\hline $\begin{array}{l}\text { Consumption } \\
\text { Non-Durables }\end{array}$ & $\underset{\text { In }}{\text { In }}$ & $\begin{array}{c}{[0]} \\
{[0]} \\
{[1,2,4,5]} \\
{[5]}\end{array}$ & $\begin{array}{l}1 \\
1 \\
1 \\
1\end{array}$ & $\begin{array}{l}0 \\
0 \\
0 \\
1\end{array}$ & $\begin{array}{l}0 \\
0 \\
0 \\
1\end{array}$ & $\begin{array}{l}0 \\
0 \\
0 \\
1\end{array}$ & $\begin{array}{l}0 \\
0 \\
0 \\
1\end{array}$ \\
\hline $\begin{array}{l}\text { Consumption } \\
\text { Non-Durables } \\
\text { per capita }\end{array}$ & $\begin{array}{l}\text { I } \\
\text { II } \\
\text { IIV }\end{array}$ & $\begin{array}{l}\text { [5] } \\
{[0]} \\
{[1]} \\
{[1]} \\
\end{array}$ & $\begin{array}{l}1 \\
1 \\
1 \\
1 \\
\end{array}$ & $\begin{array}{l}1 \\
0 \\
1 \\
1\end{array}$ & $\begin{array}{l}0 \\
0 \\
0 \\
0 \\
\end{array}$ & $\begin{array}{l}1 \\
0 \\
1 \\
1 \\
\end{array}$ & $\begin{array}{l}\mathbf{0} \\
\mathbf{0} \\
\mathbf{0} \\
\mathbf{0} \\
\end{array}$ \\
\hline $\begin{array}{l}\text { Consumption } \\
\text { Durables }\end{array}$ & $\begin{array}{l}\text { I } \\
\text { II } \\
\text { IV }\end{array}$ & $\begin{array}{l}{[0]} \\
{[0]} \\
{[0]} \\
{[0]}\end{array}$ & $\begin{array}{l}1 \\
1 \\
1 \\
1\end{array}$ & $\begin{array}{l}0 \\
0 \\
0 \\
0\end{array}$ & $\begin{array}{l}0 \\
0 \\
0 \\
0\end{array}$ & $\begin{array}{l}0 \\
0 \\
0 \\
0\end{array}$ & $\begin{array}{l}0 \\
0 \\
0 \\
0\end{array}$ \\
\hline $\begin{array}{l}\text { Consumption Durables } \\
\text { per capita }\end{array}$ & $\begin{array}{l}\text { I } \\
\text { III } \\
\text { IV }\end{array}$ & $\begin{array}{l}{[2]} \\
{[0]} \\
{[0]} \\
{[4]}\end{array}$ & $\begin{array}{l}1 \\
1 \\
1 \\
1\end{array}$ & $\begin{array}{l}0 \\
0 \\
0 \\
0\end{array}$ & $\begin{array}{l}0 \\
0 \\
0 \\
0\end{array}$ & $\begin{array}{l}0 \\
0 \\
0 \\
0\end{array}$ & $\begin{array}{l}\mathbf{0} \\
\mathbf{0} \\
\mathbf{0} \\
\mathbf{0}\end{array}$ \\
\hline
\end{tabular}

37

\begin{tabular}{|c|c|c|c|c|c|c|c|}
\hline \multirow[b]{2}{*}{ Series } & \multicolumn{2}{|c|}{ Lag Selection } & \multicolumn{5}{|c|}{ Coefficients in (3.1) } \\
\hline & Criterion & [lags] & $\pi_{1}$ & $x_{2}$ & $\pi_{3}$ & $x_{4}$ & $x_{3} \cap \pi_{4}$ \\
\hline $\begin{array}{l}\text { Consumption } \\
\text { Services }\end{array}$ & $\begin{array}{l}\text { I } \\
\text { II } \\
\text { III } \\
\text { IV }\end{array}$ & $\begin{array}{c}{[0]} \\
{[0]} \\
{[1.45]} \\
{[5]} \\
\end{array}$ & $\begin{array}{l}1 \\
1 \\
1 \\
1\end{array}$ & $\begin{array}{l}0 \\
0 \\
1 \\
1 \\
\end{array}$ & $\begin{array}{l}0 \\
0 \\
1 \\
0 \\
\end{array}$ & $\begin{array}{l}0 \\
0 \\
1 \\
1 \\
\end{array}$ & $\begin{array}{l}0 \\
0 \\
1 \\
0 \\
\end{array}$ \\
\hline $\begin{array}{l}\text { Consumption Services } \\
\text { per capita }\end{array}$ & III & $\begin{array}{c}{[7]} \\
{[5]} \\
{[1,4.5]} \\
{[5]} \\
\end{array}$ & $\begin{array}{l}1 \\
1 \\
1 \\
1 \\
\end{array}$ & $\begin{array}{l}1 \\
1 \\
1 \\
1\end{array}$ & $\begin{array}{l}1 \\
1 \\
1 \\
1 \\
\end{array}$ & $\begin{array}{l}1 \\
1 \\
1 \\
1 \\
\end{array}$ & $\begin{array}{l}1 \\
1 \\
1 \\
1 \\
\end{array}$ \\
\hline Fixed Investment & $\begin{array}{l}\text { I } \\
\text { II } \\
\text { III } \\
\text { IV } \\
\end{array}$ & $\begin{array}{l}{[0]} \\
{[0]} \\
{[1]} \\
{[1]} \\
\end{array}$ & $\begin{array}{l}1 \\
1 \\
1 \\
1 \\
\end{array}$ & $\begin{array}{l}0 \\
0 \\
0 \\
0 \\
\end{array}$ & $\begin{array}{l}0 \\
0 \\
1 \\
1 \\
\end{array}$ & $\begin{array}{l}0 \\
0 \\
0 \\
0 \\
\end{array}$ & $\begin{array}{l}0 \\
0 \\
0 \\
0 \\
\end{array}$ \\
\hline Govemment Exp. & $\begin{array}{l}\text { I } \\
\text { II } \\
\text { III } \\
\text { IV } \\
\end{array}$ & $\begin{array}{l}{[0]} \\
{[0]} \\
{[1]} \\
{[1]} \\
\end{array}$ & $\begin{array}{l}1 \\
1 \\
1 \\
1\end{array}$ & $\begin{array}{l}0 \\
0 \\
\mathbf{0} \\
0 \\
\end{array}$ & $\begin{array}{l}0 \\
0 \\
1 \\
1 \\
\end{array}$ & $\begin{array}{l}0 \\
0 \\
0 \\
0 \\
\end{array}$ & $\begin{array}{l}\mathbf{0} \\
\mathbf{0} \\
\mathbf{0} \\
\mathbf{0} \\
\end{array}$ \\
\hline $\begin{array}{l}\text { Government Exp. } \\
\text { Federal }\end{array}$ & III & $\begin{array}{l}{[0]} \\
{[0]} \\
{[0]} \\
{[0]} \\
\end{array}$ & $\begin{array}{l}1 \\
1 \\
1 \\
1 \\
\end{array}$ & $\begin{array}{l}0 \\
0 \\
0 \\
0 \\
\end{array}$ & $\begin{array}{l}1 \\
1 \\
1 \\
1 \\
\end{array}$ & $\begin{array}{l}0 \\
0 \\
0 \\
0 \\
\end{array}$ & $\begin{array}{l}0 \\
0 \\
0 \\
0 \\
\end{array}$ \\
\hline $\begin{array}{l}\text { Government Exp. } \\
\text { Defense }\end{array}$ & III & $\begin{array}{l}{[0]} \\
10] \\
10] \\
10] \\
\end{array}$ & $\begin{array}{l}1 \\
1 \\
1 \\
1 \\
\end{array}$ & $\begin{array}{l}0 \\
0 \\
0 \\
0 \\
\end{array}$ & $\begin{array}{l}0 \\
0 \\
0 \\
0 \\
\end{array}$ & $\begin{array}{l}0 \\
0 \\
0 \\
0 \\
\end{array}$ & $\begin{array}{l}\mathbf{0} \\
\mathbf{0} \\
\mathbf{0} \\
\mathbf{0} \\
\end{array}$ \\
\hline Exports & $\begin{array}{l}\text { I } \\
\text { II } \\
\text { II } \\
\end{array}$ & $\begin{array}{l}{[0]} \\
10] \\
{[1]} \\
{[1]} \\
\end{array}$ & $\begin{array}{l}1 \\
1 \\
1 \\
1 \\
\end{array}$ & $\begin{array}{l}0 \\
0 \\
1 \\
1 \\
\end{array}$ & $\begin{array}{l}0 \\
0 \\
0 \\
0 \\
\end{array}$ & \begin{tabular}{|l|}
0 \\
0 \\
0 \\
0 \\
\end{tabular} & $\begin{array}{l}0 \\
0 \\
0 \\
0 \\
\end{array}$ \\
\hline Imports & $\begin{array}{l}\text { II } \\
\text { III } \\
\text { IV }\end{array}$ & $\begin{array}{l}10] \\
101 \\
10] \\
10]\end{array}$ & $\begin{array}{l}1 \\
1 \\
1 \\
1 \\
\end{array}$ & $\begin{array}{l}0 \\
0 \\
0 \\
0\end{array}$ & $\begin{array}{l}0 \\
0 \\
0 \\
0\end{array}$ & $\begin{array}{l}0 \\
0 \\
0 \\
0\end{array}$ & $\begin{array}{l}0 \\
0 \\
0 \\
0 \\
\end{array}$ \\
\hline
\end{tabular}




\begin{tabular}{|c|c|c|c|c|c|c|c|}
\hline \multirow[b]{2}{*}{ Series } & \multicolumn{2}{|c|}{ Lag Selection } & \multicolumn{5}{|c|}{ Coefficients in (3.1) } \\
\hline & Criterion & [lags] & $\pi_{1}$ & $x_{2}$ & $\pi_{3}$ & $x_{4}$ & $\pi_{3} \cap \pi_{4}$ \\
\hline $\begin{array}{l}\text { Change in Bus. } \\
\text { Inventories }\end{array}$ & $\begin{array}{l}\text { II } \\
\text { III } \\
\text { IV }\end{array}$ & $\begin{array}{c}{[5]} \\
{[5]} \\
{[2,45]} \\
{[5]}\end{array}$ & $\begin{array}{l}0 \\
0 \\
0 \\
0\end{array}$ & $\begin{array}{l}1 \\
1 \\
0 \\
1\end{array}$ & $\begin{array}{l}1 \\
1 \\
0 \\
1\end{array}$ & $\begin{array}{l}1 \\
1 \\
0 \\
1\end{array}$ & $\begin{array}{l}1 \\
1 \\
0 \\
1\end{array}$ \\
\hline Employment & $\begin{array}{l}\text { I } \\
\text { III } \\
\text { IV }\end{array}$ & $\begin{array}{l}\text { [5] } \\
10] \\
\text { [1] } \\
{[1]} \\
\end{array}$ & $\begin{array}{l}1 \\
1 \\
1 \\
1 \\
\end{array}$ & $\begin{array}{l}1 \\
0 \\
0 \\
0 \\
\end{array}$ & \begin{tabular}{l|}
1 \\
1 \\
1 \\
1 \\
\end{tabular} & $\begin{array}{l}\mathbf{0} \\
\mathbf{0} \\
\mathbf{0} \\
\mathbf{0} \\
\end{array}$ & $\begin{array}{l}0 \\
0 \\
0 \\
0 \\
\end{array}$ \\
\hline Unemployment & II & $\begin{array}{l}\text { [S] } \\
\text { [0] } \\
\text { II] } \\
\text { [I] }\end{array}$ & $\begin{array}{l}1 \\
1 \\
1 \\
1 \\
\end{array}$ & $\begin{array}{l}1 \\
0 \\
0 \\
0 \\
\end{array}$ & $\begin{array}{l}1 \\
1 \\
1 \\
1\end{array}$ & $\begin{array}{l}0 \\
0 \\
0 \\
0 \\
\end{array}$ & $\begin{array}{l}0 \\
0 \\
0 \\
0 \\
\end{array}$ \\
\hline Average Hours & II & $\begin{array}{l}{[1]} \\
\text { [1] } \\
{[0]} \\
{[0]} \\
\end{array}$ & $\begin{array}{l}1 \\
1 \\
1 \\
1 \\
\end{array}$ & $\begin{array}{l}1 \\
1 \\
0 \\
0\end{array}$ & $\begin{array}{l}1 \\
1 \\
0 \\
0\end{array}$ & $\begin{array}{l}0 \\
0 \\
0 \\
0\end{array}$ & $\begin{array}{l}\mathbf{0} \\
0 \\
0 \\
0\end{array}$ \\
\hline Labor Force & $\begin{array}{l}\text { I } \\
\text { III } \\
\text { IV }\end{array}$ & $\begin{array}{l}\text { [1] } \\
\text { III } \\
\text { [1] } \\
\text { [1] }\end{array}$ & $\begin{array}{l}1 \\
1 \\
1 \\
1\end{array}$ & $\begin{array}{l}1 \\
1 \\
1 \\
1\end{array}$ & \begin{tabular}{l|}
1 \\
1 \\
1 \\
1
\end{tabular} & $\begin{array}{l}0 \\
0 \\
0 \\
0\end{array}$ & $\begin{array}{l}0 \\
0 \\
0 \\
0\end{array}$ \\
\hline Cons. Price Index & $\begin{array}{l}\text { I } \\
\text { II } \\
\text { IV } \\
\end{array}$ & $\begin{array}{l}{[5]} \\
{[5]} \\
{[0]} \\
10] \\
\end{array}$ & $\begin{array}{l}1 \\
1 \\
1 \\
1 \\
\end{array}$ & $\begin{array}{l}0 \\
0 \\
1 \\
1 \\
\end{array}$ & $\begin{array}{l}0 \\
0 \\
0 \\
0 \\
\end{array}$ & $\begin{array}{l}0 \\
0 \\
0 \\
0 \\
\end{array}$ & $\begin{array}{l}0 \\
0 \\
0 \\
0 \\
\end{array}$ \\
\hline Interest Rate & $\begin{array}{l}\text { I } \\
\text { II } \\
\text { IIV }\end{array}$ & $\begin{array}{l}{[5]} \\
{[5]} \\
{[4]} \\
{[4]}\end{array}$ & $\begin{array}{l}1 \\
1 \\
1 \\
1\end{array}$ & $\begin{array}{l}1 \\
1 \\
0 \\
0\end{array}$ & $\begin{array}{l}1 \\
1 \\
0 \\
0\end{array}$ & $\begin{array}{l}0 \\
0 \\
0 \\
0\end{array}$ & $\begin{array}{l}0 \\
0 \\
0 \\
0\end{array}$ \\
\hline
\end{tabular}

\begin{tabular}{|c|c|c|c|c|c|c|c|}
\hline \multirow{2}{*}{ Series } & \multicolumn{2}{|c|}{ Lag Selection } & \multicolumn{5}{|c|}{ Coefficients in (3.1) } \\
\hline & Criterion & [lags] & $\pi_{1}$ & $\pi_{2}$ & $x_{3}$ & $\pi_{4}$ & $\pi_{3} \cap \pi_{4}$ \\
\hline $\begin{array}{l}\text { Ex post real interest } \\
\text { rate }\end{array}$ & $\begin{array}{l}\text { I } \\
\text { II } \\
\text { III } \\
\text { IV }\end{array}$ & $\begin{array}{l}{[5]} \\
10] \\
10] \\
{[0]} \\
\end{array}$ & $\begin{array}{l}0 \\
0 \\
0 \\
0 \\
\end{array}$ & $\begin{array}{l}0 \\
0 \\
0 \\
0 \\
\end{array}$ & $\begin{array}{l}0 \\
0 \\
0 \\
0 \\
\end{array}$ & $\begin{array}{l}1 \\
1 \\
1 \\
1 \\
\end{array}$ & $\begin{array}{l}0 \\
0 \\
0 \\
0 \\
\end{array}$ \\
\hline Average Wage & $\begin{array}{l}\text { I } \\
\text { II } \\
\text { III } \\
\text { IV }\end{array}$ & $\begin{array}{l}{[3]} \\
{[1]} \\
{[2]} \\
{[2]}\end{array}$ & $\begin{array}{l}1 \\
1 \\
1 \\
1\end{array}$ & $\begin{array}{l}0 \\
0 \\
1 \\
1 \\
\end{array}$ & $\begin{array}{l}0 \\
1 \\
1 \\
1 \\
\end{array}$ & $\begin{array}{l}1 \\
0 \\
0 \\
0 \\
\end{array}$ & $\begin{array}{l}0 \\
0 \\
0 \\
0 \\
\end{array}$ \\
\hline Real Average Wage & $\begin{array}{r}\mathbf{I} \\
\mathbf{I I} \\
\text { III } \\
\text { IV } \\
\end{array}$ & $\begin{array}{l}{[1]} \\
{[1]} \\
{[7]} \\
{[7]}\end{array}$ & $\begin{array}{l}1 \\
1 \\
1 \\
1 \\
\end{array}$ & $\begin{array}{l}0 \\
0 \\
0 \\
0 \\
\end{array}$ & $\begin{array}{l}0 \\
0 \\
0 \\
0 \\
\end{array}$ & $\begin{array}{l}0 \\
0 \\
0 \\
0 \\
\end{array}$ & $\begin{array}{l}0 \\
0 \\
0 \\
0 \\
\end{array}$ \\
\hline Monetary Base & $\begin{array}{l}\text { II } \\
\text { III } \\
\text { IV } \\
\end{array}$ & $\begin{array}{l}{[5]} \\
{[0]} \\
{[0]} \\
{[0]}\end{array}$ & $\begin{array}{l}1 \\
0 \\
0 \\
0\end{array}$ & \begin{tabular}{|l|}
0 \\
0 \\
0 \\
0 \\
\end{tabular} & $\begin{array}{l}1 \\
1 \\
1 \\
1\end{array}$ & $\begin{array}{l}0 \\
0 \\
0 \\
0 \\
\end{array}$ & $\begin{array}{l}0 \\
0 \\
0 \\
0 \\
\end{array}$ \\
\hline Money Supply - MI & $\begin{array}{l}\text { I } \\
\text { III } \\
\text { IV } \\
\end{array}$ & $\begin{array}{c}{[5]} \\
{[2]} \\
{[1,4.5]} \\
{[5]} \\
\end{array}$ & $\begin{array}{l}1 \\
1 \\
1 \\
1 \\
\end{array}$ & $\begin{array}{l}1 \\
0 \\
0 \\
0 \\
\end{array}$ & $\begin{array}{l}1 \\
1 \\
1 \\
1 \\
\end{array}$ & $\begin{array}{l}0 \\
0 \\
0 \\
0 \\
\end{array}$ & $\begin{array}{l}0 \\
0 \\
0 \\
0 \\
\end{array}$ \\
\hline Real Balances & $\begin{array}{l}\text { I } \\
\text { II } \\
\text { III } \\
\text { IV }\end{array}$ & $\begin{array}{c}{[5]} \\
{[0]} \\
{[1.4 .5]} \\
{[5]}\end{array}$ & $\begin{array}{l}0 \\
0 \\
0 \\
0\end{array}$ & $\begin{array}{l}0 \\
0 \\
0 \\
0\end{array}$ & $\begin{array}{l}0 \\
0 \\
0 \\
0\end{array}$ & $\begin{array}{l}0 \\
0 \\
0 \\
0\end{array}$ & $\begin{array}{l}0 \\
0 \\
0 \\
0\end{array}$ \\
\hline
\end{tabular}

Based on estimates of equation (3.1). A constant, trend, and deterministic seasonal dummies are included. 
TABLE B6

U.S. Seasonally Adjusted Quarterly Data from Citibase: Sample Ends 1989.4 -value of AR Correction Lag Terms in Unit Root Test

Model includes [1, Tr

\begin{tabular}{|c|c|c|c|c|c|c|c|c|}
\hline \multicolumn{9}{|c|}{ Model includes $(\mathrm{I}, \mathrm{Tr})$} \\
\hline \multirow[b]{2}{*}{ Series } & \multicolumn{7}{|c|}{ AR Lag Length } & \multirow[b]{2}{*}{ AUG } \\
\hline & 1 & 2 & 3 & 4 & 5 & 6 & 7 & \\
\hline $\begin{array}{l}\text { Gross National } \\
\text { Product }\end{array}$ & $4.265^{\circ}$ & $2.656^{\circ}$ & -.705 & -1.122 & -.319 & -.677 & .824 & 1.2 \\
\hline $\begin{array}{l}\text { Consumption } \\
\text { Exp. }\end{array}$ & .665 & $3.181^{\circ}$ & .863 & -.947 & -1.047 & -.528 & 1.681 & 2 \\
\hline Durables & -.053 & $2.351^{\circ}$ & .386 & .153 & 1.303 & .277 &. .122 & 2 \\
\hline Nondurables & .908 & 1.018 & 1.627 & -.878 & .532 & -496 & 1.196 & 0 \\
\hline Services & 1.496 & -.079 & .715 & .637 & $-2.690^{\circ}$ & 1.284 & 1.372 & $s$ \\
\hline $\begin{array}{l}\text { Fixed } \\
\text { lnvestment' }\end{array}$ & $6.919^{\circ}$ & 1.303 & 1.107 & -1.014 & 1.182 & 504 & .153 & 1 \\
\hline Gov. Exp. & $2.708^{\circ}$ & .734 & .396 &. .103 &. .712 & .418 & -.331 & $i$ \\
\hline $\begin{array}{l}\text { Fed. \& } \\
\text { Defense" }\end{array}$ & $8.791^{\circ}$ & $2.136^{\circ}$ & -1.342 & -1.303 & 1.145 & .161 & -.889 & 1,2 \\
\hline Exports & -1.508 & 2.238 & 2.228 & 1.268 & .590 & .509 & .441 & 2.3 \\
\hline Imports & .057 & .384 & .019 & -1.347 & -.312 & $\mathbf{S 4 8}$ & .480 & 0 \\
\hline Change in Inv. & $2.487^{\circ}$ & 1.574 & $4.453^{\circ}$ & .685 & .507 & .078 & .723 & 1.3 \\
\hline Unemployment & $8.747^{\circ}$ &. .510 & -.158 & -1.515 & -.063 & 1.180 & .367 & 1 \\
\hline Employment & $5.471^{\circ}$ & .044 & .206 & .538 & -1.751 & .462 & .400 & 1 \\
\hline $\begin{array}{l}\text { Average } \\
\text { Hours }\end{array}$ & $3.384^{\circ}$ & .328 & .955 & -1.679 & .684 & -1.471 & 1.742 & 1 \\
\hline Labor Force & .228 & .244 & -.084 & $1.977^{\circ}$ & 1.215 & .348 & -.772 & 4 \\
\hline Price Lever & $8.642^{\circ}$ & -.758 & $4.612^{\circ}$ & $-3.504^{\circ}$ & 1.660 & -1.884 & 1.771 & $1,3,4$ \\
\hline Inverest Rate" & $5.235^{\circ}$ & $4.377^{\circ}$ & $4.302^{\circ}$ & -1.216 & $2.003^{\circ}$ & -.043 & $-2430^{\circ}$ & $12,3.5 .7$ \\
\hline Ex post reart & -1.338 & $-2.783^{\circ}$ & $2213^{\circ}$ & -1.689 & 1.308 & -1.399 & .577 & 2,3 \\
\hline Nominal Wage & & & $\mathrm{Not}$ & Available & & & & \\
\hline Real Wage & & & Not & Available & & & & \\
\hline Monetary Base" & $5.322^{\circ}$ & -.372 & 947 & -1.233 & 1.698 & -.978 & .190 & 1 \\
\hline $\mathrm{MI}^{4}$ & $4.809^{\circ}$ & 892 & .317 & $-2.710^{\circ}$ & $2.794^{\circ}$ & .747 & $-2.009^{\circ}$ & $1,4,5,7$ \\
\hline Real Balances & $5.738^{\circ}$ & .072 & $1.963^{\circ}$ & -1.551 & 1.914 & .637 &. .881 & 13 \\
\hline
\end{tabular}

Simplifies staistically significant at the $5 \%$ kvel.

Residential Gross Dom. Private Fixed Investment (Residential)

Federat and Defense could noe be obenined separaly

Manufacturing sector.

Quarnerly averages of monthly dint
TABLE B7

U.S. Sersonally Adjusted Quartedy Datn from Citibase: Unit Roor Dickey-Fuller Test Strtistic

\begin{tabular}{|c|c|c|c|c|c|c|}
\hline \multicolumn{7}{|c|}{$\begin{array}{c}\text { Model includes }[\mathrm{II} . \mathrm{Tr}] \\
\text {-(t"-statistic-selection criterion }\end{array}$} \\
\hline Series & $\begin{array}{c}\text { (1) } \\
\text { Longest Sign. Lag }\end{array}$ & $\begin{array}{c}\text { (2) } \\
\text { Selective Aug. }\end{array}$ & \multicolumn{2}{|c|}{$\begin{array}{l}\text { (3) } \\
\text { AIC }^{\prime}\end{array}$} & \multicolumn{2}{|c|}{$\begin{array}{l}(4) \\
S C^{2}\end{array}$} \\
\hline GNP & -3.084 & -1.993 & -1.912 & (0) & $x$ & (0) \\
\hline Cons. Exp. & -2.113 & $-2.113 x$ & -1.586 & (1) & $x$ & (1) \\
\hline Durables & $-3.582^{\circ}$ & -3.781 & -3.315 & (0) & $x$ & (0) \\
\hline Nondurables & -.906 & $-.906 x$ & -.906 & (0) & $x$ & (0) \\
\hline Services & .051 & .323 & -.305 & (7) & -.236 & (0) \\
\hline Fixed Inv. & $-5.176^{\circ}$ & $-5.176^{\circ}$ & -3.346 & (2) & 3.408 & (1) \\
\hline Gov. Exp. & -2.362 & $-2.362 x$ & -2.050 & (7) & -2.653 & (0) \\
\hline Fed. Govt. Exp. & -2.609 & $-2.609 x$ & & (7) & -2.275 & (0) \\
\hline Defense & $-3.583^{\circ}$ & $-4.497^{\circ}$ & & (7) & -1.230 & (0) \\
\hline Exports & -2.149 & -2.311 & -1.643 & (0) & $x$ & (0) \\
\hline Imports & -1.638 & $-1.638 x$ & -1.700 & (0) & $x$ & (0) \\
\hline Change in Inv. & $-7.849^{\circ}$ & $-8.000^{\circ}$ & $-6.510^{\circ}$ & (0) & $x$ & $(0)$ \\
\hline Unemployment & $-4.548^{\circ}$ & $-4.548^{\circ} x$ & -3.602 & (2) & -1.834 & (0) \\
\hline Employment & -2.716 & $-2.716 x$ & -2.418 & (6) & -1.857 & $(0)$ \\
\hline Avg. Hours & -3.295 & $-4.381^{\circ}$ & -3.304 & (0) & $x$ & (0) \\
\hline Labor Force & -2.395 & -2.457 & $-2.887-$ & (7) & -2.520 & $(0)$ \\
\hline Price Level & -1.842 & -1.849 & -1.407 & (7) & $x$ & $(7)$ \\
\hline Interest Rate & -2.503 & -2.902 & -2.939 & (4) & -2.490 & (2) \\
\hline Ex Post Real & $-3.718^{\circ}$ & $-5.615^{\circ}$ & $-3.504^{\circ}$ & (6) & $x$ & (6) \\
\hline Monctary Base & $-4.922^{\circ}$ & -2.303 & $-3.730^{\circ}$ & (4) & $-8.781^{\circ}$ & (0) \\
\hline $\mathbf{M 1}$ & -2.194 & -2.188 & -2.948 & (2) & $-3.659^{\circ}$ & (0) \\
\hline Real Balances & -2.348 & -2.303 & -2.097 & (4) & -1.927 & (2) \\
\hline
\end{tabular}

Signifies rejection of the null of a unit root at the $5 \%$ level using Mackinnon's critical values Signiles chat lag selection lecthiques (1) and (2) resulted in the same lag selection 
Seasonal Unit Root Test Results: HEGY Method'

\begin{tabular}{|c|c|c|c|c|c|c|c|}
\hline \multirow[b]{3}{*}{ Series } & \multicolumn{2}{|l|}{ Sample } & & & & & \\
\hline & Lag S & & \multicolumn{5}{|c|}{ Coefficients in (3.1) } \\
\hline & Criterion & [lags] & $\pi_{1}$ & $\pi_{2}$ & $\pi_{3}$ & $\boldsymbol{x}_{4}$ & $\pi_{g}, \pi_{4}$ \\
\hline GNP & $\begin{array}{l}\text { I. NC } \\
\text { II. SC } \\
\text { il. Augmentation } \\
\end{array}$ & $\begin{array}{l}\text { [5] } \\
\text { [5] } \\
{[1]}\end{array}$ & $\begin{array}{l}1 \\
1 \\
1 \\
\end{array}$ & $\begin{array}{l}1 \\
1 \\
0 \\
\end{array}$ & $\begin{array}{l}1 \\
1 \\
1\end{array}$ & $\begin{array}{l}0 \\
0 \\
0 \\
\end{array}$ & $\begin{array}{l}0 \\
0 \\
0 \\
\end{array}$ \\
\hline Consumption & $\begin{array}{c}\mathbf{I} \\
\mathbf{n} \\
\text { III }\end{array}$ & $\begin{array}{c}{[5]} \\
{[5]} \\
{[1,2.4,5]} \\
\end{array}$ & $\begin{array}{l}1 \\
1 \\
1 \\
\end{array}$ & $\begin{array}{l}1 \\
1 \\
1 \\
\end{array}$ & $\begin{array}{l}1 \\
1 \\
1 \\
\end{array}$ & $\begin{array}{l}0 \\
0 \\
0 \\
\end{array}$ & $\begin{array}{l}0 \\
0 \\
0 \\
\end{array}$ \\
\hline $\begin{array}{l}\text { Consumption } \\
\text { Non-Durables }\end{array}$ & II & $\begin{array}{r}{[5]} \\
{[1]} \\
{[12,4,5]} \\
\end{array}$ & $\begin{array}{l}1 \\
1 \\
1 \\
\end{array}$ & $\begin{array}{l}1 \\
1 \\
0 \\
\end{array}$ & $\begin{array}{l}1 \\
0 \\
0 \\
\end{array}$ & $\begin{array}{l}0 \\
0 \\
0 \\
\end{array}$ & $\begin{array}{l}0 \\
0 \\
0 \\
\end{array}$ \\
\hline $\begin{array}{l}\text { Consumption } \\
\text { Durebles }\end{array}$ & II & $\begin{array}{l}{[1]} \\
10] \\
01 \\
\end{array}$ & $\begin{array}{l}1 \\
1 \\
1 \\
\end{array}$ & $\begin{array}{l}0 \\
0 \\
0 \\
\end{array}$ & $\begin{array}{l}0 \\
0 \\
0 \\
\end{array}$ & $\begin{array}{l}0 \\
0 \\
0 \\
\end{array}$ & $\begin{array}{l}0 \\
0 \\
0 \\
\end{array}$ \\
\hline $\begin{array}{l}\text { Consumption } \\
\text { Services }\end{array}$ & II & $\begin{array}{c}{[s]} \\
{[s]} \\
{[1,4.5]} \\
\end{array}$ & $\begin{array}{l}1 \\
1 \\
1 \\
\end{array}$ & $\begin{array}{l}1 \\
1 \\
1 \\
\end{array}$ & $\begin{array}{l}0 \\
0 \\
1 \\
\end{array}$ & $\begin{array}{l}1 \\
1 \\
1 \\
\end{array}$ & $\begin{array}{l}0 \\
0 \\
1 \\
\end{array}$ \\
\hline Fixed Investment & $\begin{array}{c}\mathbf{1} \\
\mathbf{u} \\
\mathbf{u I}\end{array}$ & $\begin{array}{l}{[6]^{\circ}} \\
{[4]} \\
{[1]^{\circ}} \\
\end{array}$ & $\begin{array}{l}0 \\
1 \\
1 \\
\end{array}$ & $\begin{array}{l}0 \\
0 \\
0 \\
\end{array}$ & $\begin{array}{l}0 \\
0 \\
1 \\
\end{array}$ & $\begin{array}{l}0 \\
0 \\
0 \\
\end{array}$ & $\begin{array}{l}0 \\
0 \\
0 \\
\end{array}$ \\
\hline Govemment Exp. & $\begin{array}{c}\text { II } \\
\text { III }\end{array}$ & $\begin{array}{l}\text { [1]" } \\
\text { [1]" } \\
\text { [1] }\end{array}$ & $\begin{array}{l}\mathbf{0} \\
0 \\
0 \\
\end{array}$ & $\begin{array}{l}0 \\
0 \\
0 \\
\end{array}$ & $\begin{array}{l}0 \\
0 \\
0 \\
\end{array}$ & $\begin{array}{l}0 \\
0 \\
0\end{array}$ & $\begin{array}{l}0 \\
0 \\
0\end{array}$ \\
\hline $\begin{array}{l}\text { Government Exp. } \\
\text { Federal }\end{array}$ & $\underset{\mathbf{u}}{\mathbf{I}}$ & $\prod_{11}$ & $\begin{array}{l}1 \\
1 \\
1\end{array}$ & $\begin{array}{l}0 \\
0 \\
0 \\
\end{array}$ & $\begin{array}{l}0 \\
0 \\
0 \\
\end{array}$ & $\begin{array}{l}0 \\
0 \\
0 \\
\end{array}$ & $\begin{array}{l}0 \\
0 \\
0 \\
\end{array}$ \\
\hline $\begin{array}{l}\text { Government Exp. } \\
\text { Defense }\end{array}$ & II & $\begin{array}{c}{[1]} \\
{[0]} \\
{[0]^{\circ}}\end{array}$ & $\begin{array}{l}1 \\
1 \\
1 \\
\end{array}$ & $\begin{array}{l}0 \\
0 \\
0 \\
\end{array}$ & $\begin{array}{l}0 \\
0 \\
0 \\
\end{array}$ & $\begin{array}{l}0 \\
0 \\
0 \\
\end{array}$ & $\begin{array}{l}0 \\
0 \\
0 \\
\end{array}$ \\
\hline Exports & $\underset{\text { III }}{\text { II }}$ & $\begin{array}{l}{[2]} \\
{[2]} \\
{[1]}\end{array}$ & $\begin{array}{l}1 \\
1 \\
1\end{array}$ & $\begin{array}{l}0 \\
0 \\
0\end{array}$ & $\begin{array}{l}0 \\
0 \\
0\end{array}$ & $\begin{array}{l}0 \\
0 \\
0\end{array}$ & $\begin{array}{l}0 \\
0 \\
0\end{array}$ \\
\hline Imports & $\begin{array}{l}\text { II } \\
\text { III }\end{array}$ & $\begin{array}{l}{[5]} \\
10] \\
{[0]} \\
\end{array}$ & $\begin{array}{l}1 \\
1 \\
1 \\
\end{array}$ & $\begin{array}{l}0 \\
0 \\
0 \\
\end{array}$ & $\begin{array}{l}0 \\
0 \\
0 \\
\end{array}$ & $\begin{array}{l}0 \\
0 \\
0 \\
\end{array}$ & $\begin{array}{l}0 \\
0 \\
0 \\
\end{array}$ \\
\hline $\begin{array}{l}\text { Chenge in Bacas } \\
\text { Inventories }\end{array}$ & $\begin{array}{l}\text { I } \\
\text { II } \\
\text { III }\end{array}$ & $\begin{array}{c}{[5]} \\
{[3]} \\
{[2,4,5]}\end{array}$ & $\begin{array}{l}0 \\
0 \\
0\end{array}$ & $\begin{array}{l}1 \\
0 \\
0\end{array}$ & $\begin{array}{l}0 \\
0 \\
0\end{array}$ & $\begin{array}{l}0 \\
0 \\
0\end{array}$ & $\begin{array}{l}0 \\
0 \\
0\end{array}$ \\
\hline
\end{tabular}

\begin{tabular}{|c|c|c|c|c|c|c|c|}
\hline \multirow[b]{2}{*}{ Series } & \multicolumn{2}{|c|}{ Lag Selection } & \multicolumn{5}{|c|}{ Coefficients in (3.1) } \\
\hline & Criterion & [lags] & $\pi_{1}$ & $\pi_{2}$ & $\pi_{3}$ & $\pi_{4}$ & $\pi_{1} \cap \pi_{4}$ \\
\hline Employment & II & $\begin{array}{l}{[6]} \\
121 \\
{[1]} \\
\end{array}$ & $\begin{array}{l}1 \\
1 \\
1\end{array}$ & $\begin{array}{l}1 \\
0 \\
0 \\
\end{array}$ & $\begin{array}{l}1 \\
1 \\
\end{array}$ & $\begin{array}{l}0 \\
0 \\
0 \\
\end{array}$ & $\begin{array}{l}\mathbf{0} \\
\mathbf{0} \\
\mathbf{0} \\
\end{array}$ \\
\hline Unemployment & II & $\begin{array}{l}\text { [3] } \\
\text { (2) } \\
\text { i1] } \\
\end{array}$ & $\begin{array}{l}1 \\
1 \\
0\end{array}$ & $\begin{array}{l}0 \\
0 \\
0 \\
\end{array}$ & $\begin{array}{l}0 \\
1 \\
1 \\
\end{array}$ & $\begin{array}{l}0 \\
0 \\
0 \\
\end{array}$ & $\begin{array}{l}0 \\
0 \\
0 \\
\end{array}$ \\
\hline Average Hours & $\begin{array}{l}\text { I } \\
\text { III } \\
\end{array}$ & $\begin{array}{c}{[1]} \\
{[1]} \\
{[0]^{\circ}} \\
\end{array}$ & $\begin{array}{l}1 \\
1 \\
1\end{array}$ & $\begin{array}{l}0 \\
0 \\
0 \\
\end{array}$ & $\begin{array}{l}1 \\
1 \\
0 \\
\end{array}$ & $\begin{array}{l}0 \\
0 \\
0 \\
\end{array}$ & $\begin{array}{l}0 \\
0 \\
0 \\
\end{array}$ \\
\hline Labor Fonce & $\begin{array}{c}\text { I } \\
\text { II } \\
\text { III }\end{array}$ & [i1 & $\begin{array}{l}1 \\
1 \\
\end{array}$ & $\begin{array}{l}0 \\
0 \\
0 \\
\end{array}$ & $\begin{array}{l}0 \\
0 \\
1 \\
\end{array}$ & $\begin{array}{l}0 \\
0 \\
0 \\
\end{array}$ & $\begin{array}{l}0 \\
0 \\
0 \\
\end{array}$ \\
\hline Cons. Price Index & III & $\begin{array}{l}{[2]} \\
{[2]} \\
{[0]} \\
\end{array}$ & $\begin{array}{l}1 \\
1 \\
1\end{array}$ & $\begin{array}{l}0 \\
0 \\
0 \\
\end{array}$ & $\begin{array}{l}0 \\
0 \\
0 \\
\end{array}$ & $\begin{array}{l}0 \\
0 \\
0 \\
\end{array}$ & $\begin{array}{l}0 \\
0 \\
0 \\
\end{array}$ \\
\hline Interest Rate & $\begin{array}{l}\text { I } \\
\text { III } \\
\text { III }\end{array}$ & $\begin{array}{l}{[4]} \\
0] \\
{[4]} \\
\end{array}$ & $\begin{array}{l}1 \\
1 \\
1\end{array}$ & $\begin{array}{l}0 \\
0 \\
0 \\
\end{array}$ & $\begin{array}{l}0 \\
0 \\
0 \\
\end{array}$ & $\begin{array}{l}0 \\
0 \\
0 \\
\end{array}$ & $\begin{array}{l}0 \\
0 \\
0 \\
\end{array}$ \\
\hline Ex post real interest rate & $\begin{array}{c}\text { I } \\
\text { III }\end{array}$ & $\begin{array}{c}{[3]} \\
100 \\
0] \\
\end{array}$ & $\begin{array}{l}0 \\
0 \\
0\end{array}$ & $\begin{array}{l}0 \\
0 \\
0 \\
\end{array}$ & $\begin{array}{l}0 \\
0 \\
0 \\
\end{array}$ & $\begin{array}{l}1 \\
1 \\
0 \\
\end{array}$ & $\begin{array}{l}0 \\
0 \\
0 \\
\end{array}$ \\
\hline Average Wage & III & III & $\begin{array}{l}1 \\
1 \\
1\end{array}$ & \begin{tabular}{|l|}
0 \\
0 \\
0 \\
\end{tabular} & $\begin{array}{l}1 \\
1 \\
1 \\
\end{array}$ & $\begin{array}{l}0 \\
0 \\
0 \\
\end{array}$ & $\begin{array}{l}0 \\
0 \\
0 \\
\end{array}$ \\
\hline Real Average Wage & $\begin{array}{l}\text { I } \\
\text { In } \\
\end{array}$ & III & $\begin{array}{l}1 \\
1 \\
\end{array}$ & \begin{tabular}{|l|}
0 \\
0 \\
0 \\
\end{tabular} & \begin{tabular}{|l|}
0 \\
0 \\
0 \\
\end{tabular} & \begin{tabular}{|l|}
0 \\
0 \\
0 \\
\end{tabular} & $\begin{array}{l}0 \\
0 \\
0 \\
\end{array}$ \\
\hline Monetary Base & II & $\begin{array}{l}{[0]^{*}} \\
{[0]^{*}} \\
{[0]^{*}}\end{array}$ & $\begin{array}{l}1 \\
1 \\
0 \\
\end{array}$ & $\begin{array}{l}0 \\
0 \\
0 \\
\end{array}$ & $\begin{array}{l}0 \\
0 \\
0 \\
\end{array}$ & $\begin{array}{l}0 \\
0 \\
0 \\
\end{array}$ & $\begin{array}{l}0 \\
0 \\
0 \\
\end{array}$ \\
\hline Money Supply - M1 & $\begin{array}{l}\text { I } \\
\text { II } \\
\text { II } \\
\end{array}$ & $\begin{array}{l}\text { 16] } \\
\text { III } \\
{[1,4,9]}\end{array}$ & $\begin{array}{l}1 \\
1 \\
1\end{array}$ & $\begin{array}{l}1 \\
0 \\
0 \\
\end{array}$ & $\begin{array}{l}1 \\
1 \\
1\end{array}$ & $\begin{array}{l}0 \\
0 \\
0 \\
\end{array}$ & $\begin{array}{l}0 \\
0 \\
0 \\
\end{array}$ \\
\hline Real Balances & $\underset{\text { III }}{\text { II }}$ & [1] & $\begin{array}{l}1 \\
1 \\
1\end{array}$ & $\begin{array}{l}0 \\
0 \\
0 \\
\end{array}$ & $\begin{array}{l}0 \\
0 \\
1 \\
\end{array}$ & $\begin{array}{l}0 \\
0 \\
0 \\
\end{array}$ & $\begin{array}{l}0 \\
0 \\
0 \\
\end{array}$ \\
\hline
\end{tabular}

Based on estimates of equation (3.1). A constant, trend, and deterministic sensonal dummies are included. For additional details about test resulks, see the appendix.

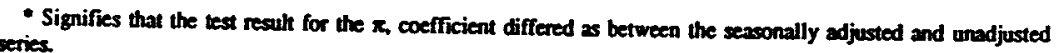

